\title{
Membrane-Anchored A $\beta$ Accelerates Amyloid Formation and Exacerbates Amyloid-Associated Toxicity in Mice
}

\author{
Amudha Nagarathinam, ${ }^{1,2,3}$ Philip Höflinger, ${ }^{1,3}$ Anika Bühler, ${ }^{1,3}$ Claudia Schäfer, ${ }^{1,3}$ Gillian McGovern, ${ }^{4}$ Martin Jeffrey, ${ }^{4}$ \\ Matthias Staufenbiel, ${ }^{1,3}$ Mathias Jucker, ${ }^{1,3}$ and Frank Baumann ${ }^{1,3}$ \\ ${ }^{1}$ Department of Cellular Neurology, Hertie Institute for Clinical Brain Research, University of Tübingen, D-72076 Tübingen, Germany, ${ }^{2}$ Graduate \\ School for Cellular and Molecular Neuroscience, University of Tübingen, D-72076 Tübingen, Germany, ${ }^{3}$ German Center for Neurodegenerative \\ Diseases, D-72076 Tübingen, Germany, and ${ }^{4}$ Animal Health and Veterinary Laboratories Agency, Lasswade Laboratory, Penicuik EH26 0PZ, \\ Midlothian, United Kingdom
}

Pathological, genetic, and biochemical hallmarks of Alzheimer's disease (AD) are linked to amyloid- $\beta$ (A $\beta)$ peptide aggregation. Especially misfolded $\mathrm{A} \beta_{42}$ peptide is sufficient to promote amyloid plaque formation. However, the cellular compartment facilitating the conversion of monomeric $\mathrm{A} \beta$ to aggregated toxic $\mathrm{A} \beta$ species remains unknown. In vitro models suggest lipid membranes to be the driving force of $A \beta$ conversion. To this end, we generated two novel mouse models, expressing either membrane-anchored or nonanchored versions of the human $\mathrm{A} \beta_{42}$ peptide. Strikingly, membrane-anchored $\mathrm{A} \beta_{42}$ robustly accelerated $\mathrm{A} \beta$ deposition and exacerbated amyloidassociated toxicity upon crossing with $\mathrm{A} \beta$ precursor protein transgenic mice. These in vivo findings support the hypothesis that $\mathrm{A} \beta$ membrane interactions play a pivotal role in early-onset $\mathrm{AD}$ as well as neuronal damage and provide evidence to study $\mathrm{A} \beta-\mathrm{membrane}$ interactions as therapeutic targets.

Key words: Alzheimer's disease; mouse model; membrane anchoring; toxicity; amyloid formation

\section{Introduction}

Alzheimer's disease $(\mathrm{AD})$ is a major threat to the growing number of elderly people worldwide. Characterized clinically by memory loss and dementia, the disease is only definitely diagnosed by postmortem demonstration of specific pathological hallmarks including extracellular aggregation of amyloid- $\beta$ (A $\beta$ ) peptides in senile plaques, intracellular accumulation of tau protein in neurofibrillary tangles, and loss of synapses as well as neurons.

Considerable evidence supports a critical role for $\mathrm{A} \beta$ peptides, namely $\mathrm{A} \beta_{42}$, in the development of $\mathrm{AD}$ pathology (Hardy and Selkoe, 2002). Mutations in amyloid- $\beta$ protein precursor (APP) and presenilin increase the relative levels of $\mathrm{A} \beta_{42}$ and cause earlyonset familial forms of AD (Haass and De Strooper, 1999). Moreover, transgenic (tg) mice exclusively expressing $\mathrm{A} \beta_{42}$ develop plaque pathology in the absence of human APP overexpression, indicating that $\mathrm{A} \beta_{42}$ is sufficient for amyloid plaque formation (McGowan et al., 2005). However, despite these studies support-

Received June 16, 2013; revised Oct. 30, 2013; accepted Nov. 1, 2013.

Author contributions: A.N. and F.B. designed research; A.N., P.H., A.B., C.S., G.M., M. Jeffrey, and F.B. performed research; A.N., A.B., C.S., G.M., M. Jeffrey, M.S., M. Jucker, and F.B. analyzed data; A.N., M. Jucker, and F.B. wrote the paper.

This project was supported by the German Research Foundation DFG Grant BA2257-2 (F.B.). We thank N. Varvel, A. Marzesco, and Y. Eisele for advice; and A. Skodras, A. Bosch, U. Obermueller, I. Breuer, M. Hruscha, C. Krueger, C. Leibssle, and J. Odenthal for experimental help and support. We are grateful to M. Mercken (Johnson \& Johnson Pharmaceutical Research \& Development) for providing the JRF/AbN/25 A $\beta$ antibody; to T. Golde for kindly providing the plasmid pAG3 BriA $\beta_{42}$; and to $M$. Faendrich for supplying recombinant $A \beta 1-40$.

Correspondence should be addressed to Frank Baumann, Hertie Institute for Clinical Brain Research, Department of Cellular Neurology, Otfried-Müller-Strasse 27,72076 Tübingen, Germany. E-mail:f.baumann@uni-tuebingen.de. DOI:10.1523/JNEUROSCI.2542-13.2013

Copyright $\odot 2013$ the authors $\quad 0270-6474 / 13 / 3319284-11 \$ 15.00 / 0$ ing a pivotal role for $\mathrm{A} \beta_{42}$ in amyloid formation, it is currently unclear how and where monomeric $\mathrm{A} \beta$ initially aggregates.

Converging evidence suggests that plasma membranes may play an important role in the misfolding and aggregation of amyloidogenic proteins. First, pathological examination of AD brain material reveals early deposition on cell surface plasma membranes, forming diffuse plaques in $\mathrm{AD}$ subjects (Yamaguchi et al., 2000 ). Second, $A \beta$ has been identified in lipid raft fractions isolated from human AD brains and APP tg mice (Lee et al., 1998; Kawarabayashi et al., 2004). Finally, the membrane can act as a catalytic site, enhancing the misfolding and aggregation of amyloidogenic proteins (Chi et al., 2008). Together, these findings suggest that $\mathrm{A} \beta$ association with cellular membranes may be a pivotal event in the formation and propagation of cerebral amyloidosis (Williamson and Sutherland, 2011). However, the ability for membrane-associated $\mathrm{A} \beta$ to enhance $\mathrm{A} \beta$ deposition has, thus far, not been examined in vivo.

To address this, we have generated transgenic mice that exclusively express a membrane-anchored version of the human $\mathrm{A} \beta_{42}$ peptide. To do so, the peptide was tethered to the cell membrane via a C-terminal glycosylphosphatidyl inositol (GPI) anchor. Our results demonstrate that membrane-anchored $\mathrm{A} \beta_{42}$ is targeted to sphingolipid-rich subdomains of detergent-resistant membranes (DRMs), accelerates amyloid formation, and exacerbates amyloid-associated toxicity in vivo compared with a similar but nonanchored version of $\mathrm{A} \beta_{42}$.

\section{Materials and Methods}

Cloning of $p B r i A \beta e G P I$ and $p$ BriA $\beta$ e expression constructs. As a source for $\operatorname{BriA} \beta_{42}$, the plasmid pAG3 BriA $\beta_{42}$ (Lewis et al., 2001) was used. A 491 
bp fragment was amplified using the primers $\mathrm{A} \beta_{42}$ ( $5^{\prime}$-GTTGAATTTA TCAGTGTGCC- $3^{\prime}$ ) and XbaI A $\beta_{42}$-reverse (5'-AAACTCTAGACGCT ATGACAACACC- $3^{\prime}$ ), introducing a unique $\mathrm{XbaI}$ site instead of a stop codon into the original sequence. Similarly, using the prion protein $(\operatorname{PrP})$ coding plasmid pPrPHG (Fischer et al., 1996) as a template, $109 \mathrm{bp}$ fragments were amplified. For pBriA $\beta$ e, the primers XbaI-GPI (5'-GC GTCTAGAGACGGGAGAAGATCCTGATGAAC-3') and BamHI-reverse ( $5^{\prime}$-TAGTGGATCCTCATCCCACGATC- $\left.3^{\prime}\right)$, and for pBriAßeGPI, the primers XbaI GPI (5'-GCGTCTAGAGACGGGAGAAGATCC-3') and BamHI-reverse were taken. After purification of the fragments, they were treated with $\mathrm{XbaI}$ to generate adhesive ends. Equimolar mixtures of the respective fragment combinations and pCR 2.1 Topo Vector were mixed and transfected into DH5 $\alpha$ Escherichia coli. pCR 2.1 topo clones with correct restriction patterns were treated with BglII/BamHI to liberate 481 bp fragments either for GPI anchoring or just extended $A \beta$. These were ligated into the previous opened pAG3 $\mathrm{BriA} \beta_{42}$ to give rise to either pAG3 BriA $\beta$ e or pAG3 BriA $\beta$ eGPI. After sequence confirmation, these $\mathrm{CMV}$-driven plasmids were used for HEK cell transfections. To generate expression vectors for pronuclei injection, the respective pAG3 BriA $\beta$ e and pAG3 BriAßeGPI were subjected to XhoI restriction digest. This liberated the coding sequence of the desired BriA $\beta$ e or BriA $\beta$ eGPI of 1099 bp containing start and stop codons, which were ligated into the XhoI site of the pTSC21K vector containing the Thyl promoter (Sturchler-Pierrat et al., 1997).

Generation of transgenic mice. Transgenic mice were generated by pronuclei injection on a C57BL/6 genetic background and kept hemizygous. Intercrossings were set up with male $\mathrm{A} \beta \mathrm{eGPI}$ or $\mathrm{A} \beta \mathrm{e}$ mice and APP23 female mice all kept on C57BL/6 genetic background.

Cell lysis and protein extraction. Cells were washed with cold PBS, scraped off the plate using a cell scraper and transferred to $1.5 \mathrm{ml}$ Eppendorf tubes. Cells were subjected to centrifugation at $800 \times g$. Temperature during the whole procedure was maintained at $4^{\circ} \mathrm{C}$. The pellets were lysed with STEN-lysis buffer (50 mm Tris pH 7.6, $150 \mathrm{~mm} \mathrm{NaCl,} 2 \mathrm{~mm}$ EDTA, $0.2 \%$ Igepal CA-630, 0,1\% Triton X-100 dissolved in distilled $\mathrm{H}_{2} \mathrm{O}$ ) and incubated on ice for $15 \mathrm{~min}$ in the presence of protease inhibitor (Complete, Roche). The lysates were cleared by centrifugation at $16,000 \times g$ for $30 \mathrm{~min}$. Ten to $20 \mu \mathrm{g}$ of protein was used for analysis via Western blots.

Crude membrane isolation and protein extraction. Cells were washed with cold PBS and transferred to $1.5 \mathrm{ml}$ Eppendorf tubes placed on ice. The cells were subjected to centrifugation at $200 \times g$ for $5 \mathrm{~min}$ at $4^{\circ} \mathrm{C}$. The pellet was suspended in $200 \mu$ l of cold hypotonic buffer $(10 \mathrm{~mm}$ Tris $\mathrm{Cl}$, pH 7.5, 10 m NaCl, 0.1 mм EGTA, 25 mм $\beta$-glycerophosphate, $1 \mathrm{~mm}$ DTT dissolved in distilled $\mathrm{H}_{2} \mathrm{O}$, adjusted to $\mathrm{pH}$ 7.4) and incubated on ice for $15 \mathrm{~min}$. The cell suspension was then passed through a $1 \mathrm{ml}$ syringe with a 0.6 -mm-diameter needle for 15 times. Cell debris and nuclear fractions were pelleted by centrifugation at $200 \times g$ for $15 \mathrm{~min}$. at $4^{\circ} \mathrm{C}$. The supernatant was transferred to new Eppendorf tubes and centrifuged at $100,000 \times \mathrm{g}$ for $1 \mathrm{~h}$ at $4^{\circ} \mathrm{C}$ to obtain a membrane fraction pellet. The membrane pellet samples were suspended in NuPage loading dye and analyzed by Western blot.

Western blotting. Cell and brain extracts were analyzed on NuPage Bis-Tris mini gels (Invitrogen). Proteins were transferred to nitrocellulose membrane in a NuPage semi-dry blotting chamber and the transfer was confirmed by Ponceau-S stain. The membrane was boiled at $95^{\circ} \mathrm{C}$ for 5 min and subsequently blocked using $5 \%$ milk in PBS containing $0.1 \%$ Tween-20 (Carl Roth) for $1 \mathrm{~h}$. Blots were incubated with 6E10 antibody [epitope amino acids 3-8 of $\beta$-amyloid; EFRHDS, Covance] solution overnight at $4^{\circ} \mathrm{C}$ and later incubated with secondary antibody conjugated to horseradish peroxidase (Promega) for $1 \mathrm{~h}$ at room temperature. Chemiluminescent peroxidase substrate (ECL Plus, GE Healthcare) was used for detection. Chemiluminescence was recorded using an ECL imager (Stella 3200, Raytest), and protein bands were quantified using the software package Aida. Statistical analysis was performed using GraphPad Prism 5. Bonferroni's post hoc test for multiple comparisons was used to determine significant differences between the protein levels of different samples analyzed on Western blot.

Cell surface biotinylation of $A \beta$. Surface of intact adherent cells was treated with Biotin (Dynabeads Streptavidin Trial Kit, Invitrogen) or mock treated with PBS according to the manufacturer's instructions. The biotinylated proteins were immunoprecipitated with streptavidin beads, eluted in sample loading buffer by boiling at $95^{\circ} \mathrm{C}$ for $5 \mathrm{~min}$. Proteins were resolved by $12 \%$ NuPage gels. Samples were analyzed using Western blot probed with anti-A $\beta$-specific monoclonal antibody $6 \mathrm{E} 10$.

Immunocytochemistry. Cells were cultured on poly-L-lysine-coated glass coverslips to $50-60 \%$ confluence, fixed in $4 \%$ paraformaldehyde for $10 \mathrm{~min}$, washed with PBS twice, and blocked with 5\% BSA for $45 \mathrm{~min}$. Cells were then incubated with primary antibodies $(A \beta$ monoclonal antibody $6 \mathrm{E} 10$, dilution $1: 1000$; and $\mathrm{N}$-terminally processed $\mathrm{A} \beta$ monoclonal antibody N/25 epitope amino acids 1-7 (DARFRHD), dilution 1:500) for $2 \mathrm{~h}$ in $1 \% \mathrm{BSA}$ and kept in the dark. The cells were gently washed three times with PBS. Primary antibodies were detected by Alexa Fluor 488 (diluted 1:1000 in 1\% BSA) conjugated secondary antibody (Invitrogen) and incubated for $1 \mathrm{~h}$. DAPI (diluted 1:1000 in 1\% BSA) (Invitrogen) was added to cells for 15 min to stain the nucleus. Coverslips were gently washed twice with distilled $\mathrm{H}_{2} \mathrm{O}$ and mounted on glass slides using Immu-Mount (Thermo Scientific). Images were acquired on confocal inverted microscope. (LSM 510 laser scanning microscope, Zeiss).

Isolation of DRM fractions. DRMs were prepared on ice by detergent extraction using a previously described method (Naslavsky et al., 1997) with adaptations described in Baumann et al. (2007). Cell or brain extracts were suspended in 9\% sucrose dissolved in PBS, homogenized with a $1 \mathrm{ml}$ syringe with a $0.6-\mathrm{mm}$-diameter needle 10 times and centrifuged at $100 \times g$ for $5 \mathrm{~min}$. The protein concentration of the supernatant for the samples was determined by BCA assay, and adjusted to $1 \mathrm{mg} / \mathrm{ml}$. Samples were extracted at $4^{\circ} \mathrm{C}$ with Triton X-100 (1\% final) in $2 \mathrm{ml}$ Eppendorf tubes and placed in a tube rotator for $2 \mathrm{~h}$ at $4^{\circ} \mathrm{C}$. The Triton extract was mixed with $60 \%$ OptiPrep (Invitrogen) and transferred to $13.2 \mathrm{ml}$ centrifuge tubes (Beckman Coulter), giving a 40\% final concentration, and then was overlaid with $30 \%$ and $5 \%$ OptiPrep. Tubes were placed in a SW 41 Ti rotor (Beckman Coulter). Gradient was harvested in $400 \mu \mathrm{l}$ aliquots after $20 \mathrm{~h}$ of $200,000 \times g$ centrifugation. Fractions were suspended in sample buffer (NuPage loading dye $+10 \% \beta$-mercaptoethanol), boiled for $10 \mathrm{~min}$ at $70^{\circ} \mathrm{C}$, and analyzed on Western blot.

Phospholipase $C$ treatment. The cells were washed with ice-cold PBS, scraped off the plate in PBS, and transferred to $1.5 \mathrm{ml}$ Eppendorf tubes placed on ice. The cells were subjected to centrifugation at $200 \times g$ for 5 min at $4^{\circ} \mathrm{C}$. The pellet was suspended in buffer $(0.32 \mathrm{M}$ sucrose, $20 \mathrm{~mm}$ Tris- $\mathrm{HCl}$, and $5 \mathrm{~mm}$ EDTA, $\mathrm{pH}$ 7.5). The cell suspension was then passed through a $1 \mathrm{ml}$ syringe with a 0.6 - $\mathrm{mm}$-diameter needle 10 times and centrifuged at $3000 \times g$ for $10 \mathrm{~min}$ at $4^{\circ} \mathrm{C}$. To obtain a membrane pellet, the supernatant was centrifuged at $100,000 \times g$ for $45 \mathrm{~min}$ at $4^{\circ} \mathrm{C}$. The membrane pellet was suspended in $30 \mu \mathrm{l}$ of $20 \mathrm{~mm}$ Tris- $\mathrm{HCl}$ with $5 \mathrm{~mm}$ EDTA, pH 7.5. Fifteen microliters of membrane suspension was incubated for $2 \mathrm{~h}$ at $37^{\circ} \mathrm{C}$ with $20 \mathrm{U} / \mathrm{ml}$ recombinant Bacillus cereus phospholipase C (PLC) to release GPI-anchored membrane proteins. The remaining $15 \mu \mathrm{l}$ were untreated and served as a control. PLCtreated and nontreated samples were centrifuged at $100,000 \times g$ to separate the PLC-released proteins from the insoluble membrane fraction. The supernatant consisting of PLC-released proteins was subjected to $45 \%$ ammonium sulfate precipitation. The pellet and supernatant sample were suspended in buffer (NuPage loading dye + $10 \% \beta$-mercaptoethanol), boiled for $10 \mathrm{~min}$ at $70^{\circ} \mathrm{C}$, and analyzed on Western blot. For immunocytochemistry, cells were treated for 30 min with $20 \mathrm{U} / \mathrm{ml}$ recombinant $B$. cereus $\mathrm{PLC}$ at $37^{\circ} \mathrm{C}$, then fixed with $4 \%$ paraformaldehyde (PFA) and stained with monoclonal anti-A $\beta$ antibody N25 (Vandermeeren et al., 2001).

Proteinase K digestion. One hemisphere of mouse brain was homogenized with a Precellys tissue homogenizer to render a 20\% (w/v) extract in PBS. Brain extracts (30 $\mu \mathrm{g}$ ) were treated with $100 \mu \mathrm{g} / \mathrm{ml}$ Proteinase K (PK; Roche Diagnostics) for $30 \mathrm{~min}$ at $37^{\circ} \mathrm{C}$ with agitation at $400 \mathrm{rpm}$. The protease digestion was stopped by boiling the samples at $95^{\circ} \mathrm{C}$ for 5 min. Samples were suspended in buffer (NuPage loading dye $+10 \%$ $\beta$-mercaptoethanol), boiled for $10 \mathrm{~min}$ at $70^{\circ} \mathrm{C}$, and analyzed on Western blot.

In vitro thioflavin T aggregation assay. To determine the in vitro fibrillization potential of brain extracts a Thioflavin T fibrillization kinetic was measured as described by Colby et al. (2007) with some modifications: 
Thioflavin T was dissolved in water generating a $200 \mu \mathrm{M}$ stock solution. Lyophylized recombinant $\mathrm{A} \beta 1-40$ peptide was dissolved to a stock concentration of $5 \mathrm{~mm}$ in $100 \%$ DMSO and frozen at $-80^{\circ} \mathrm{C}$. Before use, this stock was then freshly diluted in DMSO 1:5 to $1 \mathrm{~mm}$ and sonified for 10 min in a water bath followed by 5 min centrifugation at $16,100 \times g$ at room temperature. The supernatant was then further diluted to reach $250 \mu \mathrm{M} \mathrm{A} \beta 1-40$ in a 50\% DMSO stock. Brain homogenates for this assay were prepared as follows: a crude $20 \%(\mathrm{w} / \mathrm{v})$ homogenate in PBS was made, then cleared for $5 \mathrm{~min}$ at $800 \times g$ and the supernatant diluted with additional PBS to yield a $10 \%(\mathrm{w} / \mathrm{v})$ homogenate. BCA was performed to determine total protein content. For the kinetic measurement in 96-well format, $14 \mu \mathrm{g}$ of brain homogenate in the presence of protease inhibitor cocktail from (Complete, Roche), $20 \mu \mathrm{M}$ Thioflavin T, $25 \mu \mathrm{M}$ A $\beta 1-40,50$ mM phosphate, and $150 \mathrm{~mm} \mathrm{NaCl}$ were incubated at $37^{\circ} \mathrm{C}$. Each brain homogenate was assayed in eight sealed wells of the 96-well clear-bottom plates (Greiner Bio-One). Thioflavin T fluorescence at $480 \mathrm{~nm}$ was measured from the plate bottom every 30 min using a BMG FLUOstar plate reader. Before each measurement, a double-orbital shaking step for $30 \mathrm{~s}$ with $500 \mathrm{rpm}$ was performed. Increase of fluorescence over time was followed until the maximum was reached. Raw data were fitted and lag times were determined following the equations described by Nielsen et al. (2001) with GraphPad Prism 5.

Histological analysis. Mice were perfused with PBS and excised brains post-fixed for $48 \mathrm{~h}$ in $4 \%$ PFA dissolved in PBS, then cryoprotected in $30 \%$ sucrose in PBS for $24 \mathrm{~h}$. After freezing, 25- $\mu \mathrm{m}$-thick coronal sections were sliced through the fixed brains using a freezing-sliding microtome. The sections were collected in $0.1 \mathrm{~m}$ Tris-buffered saline, $\mathrm{pH}$ 7.4, and stained immunohistochemically. The polyclonal antibody $\mathrm{CN} 3$ (Eisele et al., 2010; 1:1000) was used for immunostaining A $\beta$. The sections were all co-stained with Congo red and imaged under bright-field illumination. The following additional antibodies were used: rabbit polyclonal antibody against cow glial fibrillary acidic protein (GFAP; Dako; 1:1000); rabbit polyclonal antibody against ionized calciumbinding adapter molecule 1 (Iba1; Wako; 1:2000); cresyl violet; AT8hyperphosphorylated tau (1:1000), and 5313 antibody-APP-positive dystrophic boutons (1:2000). Images were acquired on a Zeiss Axioplan 2 microscope (Carl Zeis MicroImaging).

Stereological quantification. Stereological quantification of total parenchymal $A \beta$ covered area was performed with the Stereologer software and a motorized $\mathrm{x}-\mathrm{y}-\mathrm{z}$ stage, which is coupled to a videomicroscopy system (Systems Planning and Analysis; Calhoun et al., 1998). Frontal, neo, and entorhinal cortex were defined using a standard mouse brain atlas (Franklin and Paxinos, 2004). Quantification was performed on the left hemisphere of the brain sections. A series of coronal-cut $25 \mu \mathrm{m}$ free-floating sections stained for $\mathrm{A} \beta$ amyloid plaque deposition was analyzed. Every section starting from the frontal to the entorhinal cortex were counted to determine an overall plaque load. Thus, the analyses per transgenic animal included 10-12 sections. The amyloid load (percentage) was determined by calculating the areal fraction of parenchymal $\mathrm{A} \beta$, in two-dimensional sectors at a single focal plane at $20 \times$ and 0.45 numerical aperture (NA). Statistical analysis was performed using GraphPad Prism 5. The stereological quantification scale implied a nonsymmetric distribution; therefore, the Kruskal-Wallis non-parametric ANOVA with Dunn's multiple comparisons test was performed.

Quantification of inflammatory response. Quantification was performed on the left hemisphere of coronal brain sections. A series of 25 $\mu \mathrm{m}$ free-floating sections stained for GFAP or Ibal were imaged using a Zeiss Axioplan 2 microscope with an Axiocam HRc color camera (Carl Zeiss MicroImaging), using a Zeiss $4 \times$ and 0.1 NA Achroplan objective and the MosaiX bundle on the Axiovision 4.7 acquisition software. Every second section starting from the frontal to the entorhinal cortex was manually delineated in ImageJ and Rényi entropy measure (Kapur et al., 1985) was used to automatically determine the threshold on the red channel of the color image. The percentage of the covered area was directly calculated by the Fiji plugin as a ratio between the selected cortex area and the thresholded structures. Statistical analysis (one-way ANOVA Bonferroni multiple-comparisons test) was done using GraphPad Prism 5.

\section{Results}

\section{Generation of anchorless and GPI-anchored $\mathrm{A} \boldsymbol{\beta}_{42}$}

We modified the previously described construct BriA $\beta_{42}$ (Lewis et al., 2001) to assess the effect of membrane-bound $\mathrm{A} \beta$ on amyloidosis and associated pathologies in an AD mouse model. Expression of the $\operatorname{BriA} \beta_{42}$ construct results in secretion of the encoded $\mathrm{A} \beta$ peptide immediately after cleavage by furin-like protease of the fusion protein in the Golgi compartment.

To anchor $\mathrm{A} \beta$ to the plasma membrane, the $\operatorname{BriA} \beta_{42}$ construct was modified with the GPI anchor of the PrP. We exploited the fact that $\operatorname{PrP}$ is synthesized as a precursor protein with a classic C-terminal transmembrane domain. Under normal PrP synthesis, this domain is proteolytically processed and replaced by a GPI anchor via a transamidase reaction immediately after synthesis in the endoplasmic reticulum (ER). The cleavage signal and GPI attachment site are coded within the last 31 aa (Baumann et al., 2009; Rutishauser et al., 2009). However, only the last 24 C-terminal aa of the transmembrane domain are replaced by the GPI anchor, leaving 7 aa (SRDGRRS) added to the BriA $\beta_{42}$ peptide sequence (Fig. 1A). Thus, GPI-anchored A $\beta_{42}$ (referred to as $\mathrm{A} \beta \mathrm{eGPI}$ ) contains this 7 aa extension. As a control, we devised an additional construct encoding a secreted C-terminally extended $\mathrm{A} \beta_{42}$ (referred to as $\mathrm{A} \beta \mathrm{e}$ ) that will not be bound to the membrane (Fig. 1A).

\section{Expression and localization of GPI-anchored and anchorless A $\boldsymbol{\beta}_{42}$ in HEK293 cells}

The expression and processing of the pBriA $\beta e G P I$ and $p B r i A \beta e$ constructs function as expected in vitro after stable expression in HEK293 cells (Fig. $1 B, C$ ). Furin-like cleavage of pBriA $\beta$ eGPI produced the membrane-bound $A \beta e G P I$ (Fig. $1 B$ ). In contrast to $A \beta e$, membrane-bound $A \beta e G P I$ was confirmed by surface biotinylation (Fig. 1C). Other membrane-bound precursor proteins like APP, pBriA $\beta e G P I$, and $\mathrm{pBriA} \beta \mathrm{e}$, which were also biotinylated under these conditions, served as the internal control (Fig. 1C).

To determine whether A $\beta$ GPI was enriched in DRMs, Triton $\mathrm{X}-100$ extraction from cell homogenates was performed as described previously (Lingwood and Simons, 2007). Similar to GPIanchored PrP, A $\beta$ eGPI was found in the DRM fraction, while $\mathrm{A} \beta \mathrm{e}$ and endogenous APP remained in the loading fraction (Fig. $1 D)$. The pBriA $\beta$ eGPI, which was not yet cleaved by furin, also associated with DRMs, while the noncleaved pBriA $\beta$ e did not (Fig. 1E). These data confirm the order of events, with the transamidase attaching the GPI anchor already in the ER and targeting DRMs, while furin-like cleavage is a downstream event of the Golgi compartment. Finally, cell survival and morphology were not affected in the transfected cells, and cultures displayed similar growth rates. The monoclonal $\mathrm{A} \beta$ antibody $\mathrm{N} / 25$, recognizing the free $\mathrm{N}$ terminus of $\mathrm{A} \beta$ epitope amino acids $1-7$ (DARFRHD; Vandermeeren et al., 2001; Mathews et al., 2002), allowed for detection of $\mathrm{A} \beta \mathrm{eGPI}$ and $\mathrm{A} \beta \mathrm{e}$ in immunofluorescent microscopy (Fig. $1 F$ ). A small amount of A $\beta$ e was still sticking to cells, suggesting that $A \beta e$ interacts with cell membrane. In contrast to $\mathrm{A} \beta \mathrm{e}, \mathrm{A} \beta \mathrm{eGPI}$ displayed a strong punctuated staining on the cell membrane surface.

To test for the presence of a GPI anchor in A $\beta$ eGPI-expressing cells, HEK cells stably expressing the fusion proteins were treated with PLC. PLC cleaves the phosphodiester bond in the GPI anchor and subsequently releases the GPI-anchored $\mathrm{A} \beta$ from the cellular membrane surface (Fig. $2 A, B$ ). Only A $\beta$ eGPI was released and found in the soluble supernatant, while endogenous $\mathrm{APP}$, and the peptide transmembrane domains $\mathrm{pBriA} \beta \mathrm{eGPI}$ and 
A

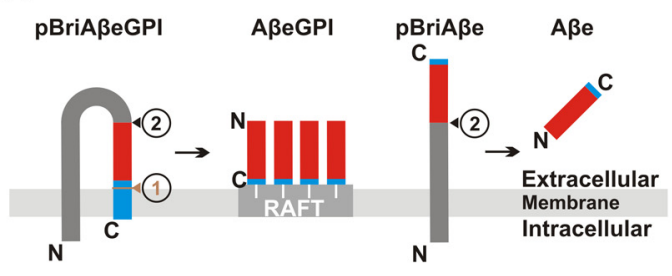

B

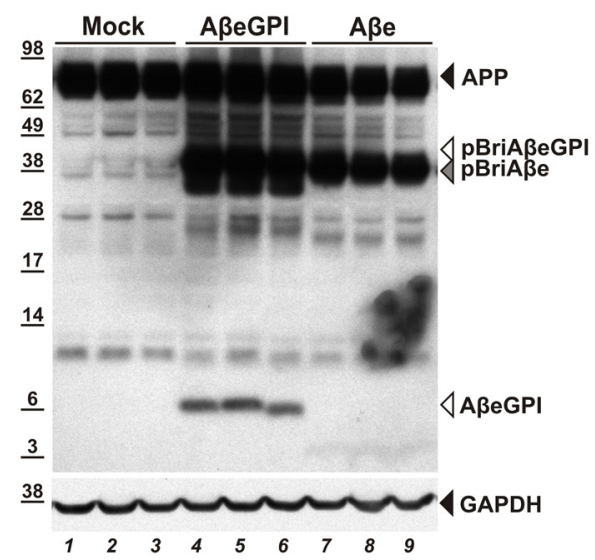

C

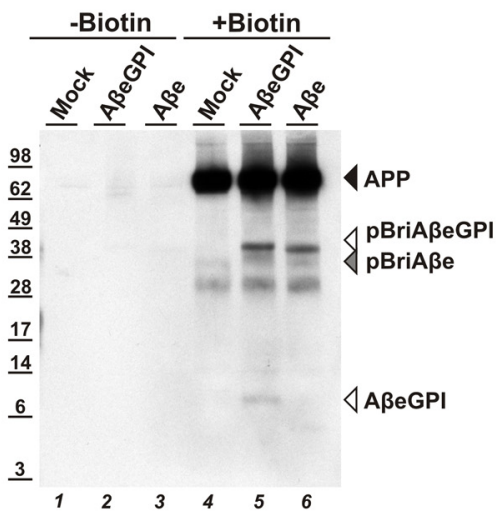

D

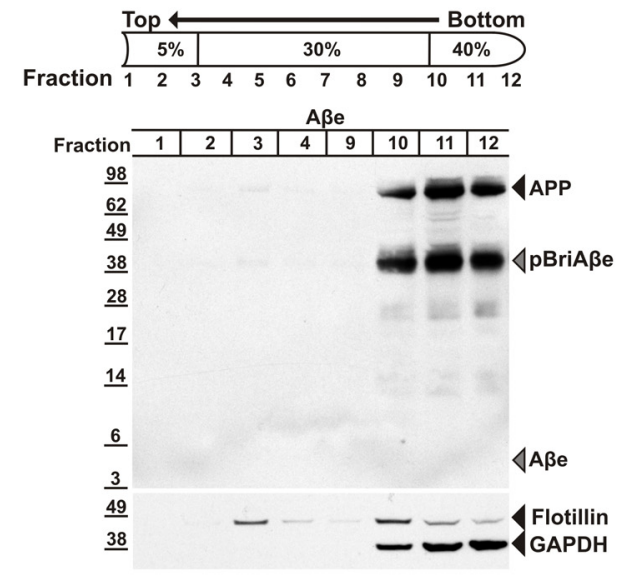

E

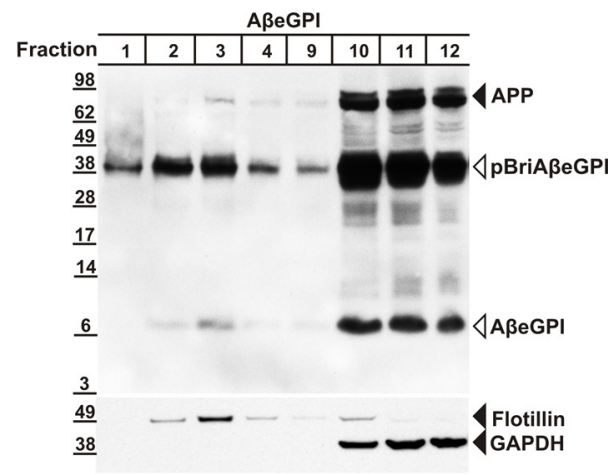

$\mathbf{F}$
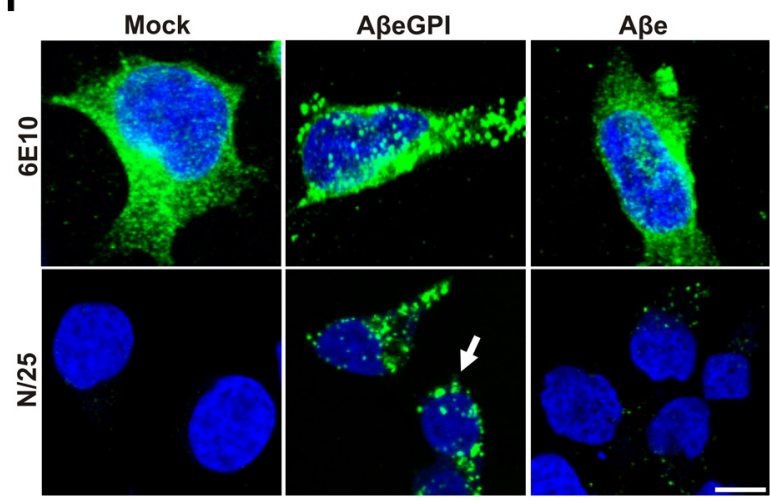

Figure 1. Membrane-anchored AßeGPI is stably expressed in HEK cells and localizes in rafts on cell membrane surfaces. $A$, Schematic representation of fusion constructs pBriA $\beta$ eGPI and $\mathrm{pBriA} \beta$ e. Briz precursor sequence (dark gray), $A \beta_{42}$ peptide (red), GPI attachment signal of PrP (blue), and raft compartment in the membrane (RAFT). (1), Corresponding to the recognition site of the GPI-transamidase replacing the transmembrane domain of pBriA $\beta$ eGPI with the GPI anchor (white lines), leaving 7 aa (SRDGRRS) as a C-terminal extension (small blue) to the $A \beta$ sequence. (2), Representing furin-like cleavage, releasing the N-terminus of $A \beta$ from the $p B r i A \beta$ eGPI sequence. The control construct $p B r i A \beta$ e with the SRDGRRS extension (2) liberating anchorless $A \beta$ e. $B$, Membrane extracts of HEK 293 (Mock), HEK A $\beta$ eGPI, and HEK A $\beta$ e cells contain A $\beta$ eGPI (lanes 4-6), and the anchored precursor proteins APP (lanes 1-9), pBriA $\beta$ eGPI (lanes 4-6), and pBriA $\beta$ e (lanes 7-9), but not A $\beta$ e (lanes 7-9). C, Cell surface association confirmed by surface biotinylation for A $\beta$ eGPI (lane 5). Transmembrane proteins like APP (lanes 4-6), pBriA $\beta$ e (lane 6), and pBriA $\beta$ eGPI are also biotinylated, but soluble $A \beta$ e is not (cell lines are as denoted in $\boldsymbol{B}$ ). $\boldsymbol{D}$, Fractions of $400 \mu \mathrm{l}$ from top to bottom of the centrifuge were collected and analyzed by Western blot and probed with $A \beta$ antibody 6E10. HEK A $\beta$ e cells show hardly any cleaved $A \beta$ in DRMs (fraction 3). pBriA $\beta$ e, though being membrane associated, is not floating similar to APP. $E$, HEK A $\beta$ eGPI demonstrate that the uncleaved precursor pBriA $\beta$ eGPI is floating with equal buoyancy as maturely processed A $\beta$ eGPI due to the GPI anchor being immediately attached after translocation in the ER (fraction 3). Flotillin-1 was used as a marker for DRMs, while the cytoplasmic protein GAPDH served as a control. $\boldsymbol{F}, \mathrm{A} \beta \mathrm{eGPI}$ is detected on the cell surface. Confocal images showing maximum projection of $0.39 \mu \mathrm{m} z$-stacks in nonpermeabilized HEK 293 (Mock), HEK A $\beta$ e, and HEK A $\beta$ eGPI cells. The top lane is stained with 6 E10 epitope (EFRHDS) detecting APP, pBriA $\beta$ e, and pBriA $\beta$ eGPI, while the bottom lane is stained with N/25, specifically detecting the free $\mathrm{N}$ terminus of processed A $\beta$ (DAEFRHD). Only HEK A $\beta$ eGPI cells show strong punctuated staining (green) on the cell surface (arrow), indicating raft association.

pBriAße remained unaffected by PLC treatment (Fig. $2 B$ ). The molecular mass of PLC-cleaved A $\beta$ eGPI appeared similar to the molecular mass of membrane-anchored A $\beta \mathrm{eGPI}$, due to the presence of the conjugated sugars and phosphate group on the liberated peptide. Immunofluorescence confirmed the sensitivity of A $\beta$ eGPI for PLC treatment (Fig. $2 C$ ).

\section{$\mathrm{A} \beta \mathrm{eGPI}$ and $\mathrm{A} \boldsymbol{\beta}$ e expression in transgenic mice}

The mouse Thyl promoter (Andrä et al., 1996) was used to drive transgene expression. Mice were generated by pronuclei injections. Three tg lines for $A \beta e$ and eight tg lines for $A \beta e G P I$ were established on a C57BL/6 genetic background. Two tg lines for $\mathrm{A} \beta \mathrm{e}$ and $\mathrm{A} \beta \mathrm{eGPI}$ were backcrossed twice to $\mathrm{C} 57 \mathrm{BL} / 6$ mice, and 

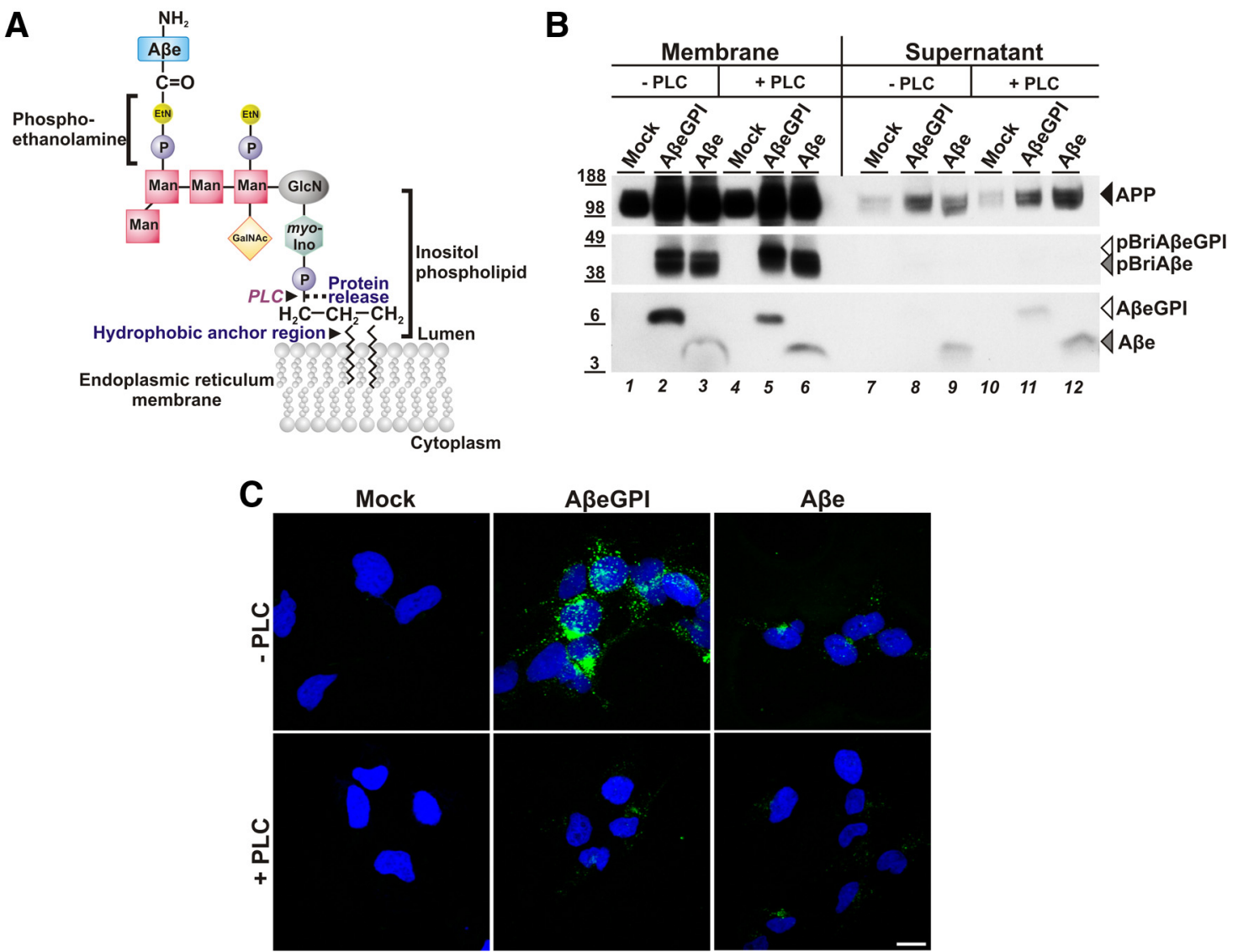

Figure 2. Membrane-anchored A $\beta$ eGPl is released by Phospholipase C (PLC) treatment. $A$, The GPI anchor with which A $\beta$ eGPI (blue box representing the whole $A \beta$ e protein) is tethered to the cell membrane is depicted schematically on the left. Cleavage site of PLC is indicated at the phosphate group (P). EtN, ethanolamine; GlcN, glucosamine; Man, mannose; myo-Ino, myo-inositol; GalNAc, N-acetylgalactosamine. B, Cell membrane fraction and supernatants of HEK 293 cells (mock), HEK A $\beta$ eGPI, and HEK A $\beta$ e, after treatment of cells with PLC (+ PLC, lanes $4-6$ and $10-12$ ) or vehicle (-PLC, lanes 1-3,7-9), were analyzed by Western blot probed with $A \beta$ antibody 6 E10. C, A $\beta$ eGPl is liberated by PLC treatment. Confocal images showing maximum projection of 0.39 $\mu \mathrm{m} z$-stacks in nonpermeabilized HEK 293 (mock), HEK Aße, and HEK AßeGPI cells stained with N/25.

showed robust expression of their respective transgene. From each mouse strain, the higher-expressing line was chosen for further analysis (Fig. 3). In the two mouse lines, the $\mathrm{A} \beta \mathrm{e}$ concentration was slightly higher than the $\mathrm{A} \beta \mathrm{eGPI}$ concentration (Fig. $3 A, C)$. Steady-state levels of $\mathrm{A} \beta \mathrm{e}$ and $\mathrm{A} \beta \mathrm{eGPI}$ did not change over time, whereas APP23 mice-a well established model for A $\beta$ plaque deposition (Sturchler-Pierrat et al., 1997)—exhibited a dramatic increase in $A \beta$ due to deposition of insoluble $A \beta$ plaques beyond 9 months of age (Fig. $3 B, C$ ). Histological analysis of $A \beta e$ and $A \beta e G P I$ mice displayed neither plaque formation (Fig. $3 D$ ) nor other alterations (e.g., activation of astrocytes, proliferation of microglia; data not shown) up to 24 months of age. Lack of $A \beta e$ deposition, independent of the GPI membrane anchoring, could be due to the lower levels of $A \beta$ compared with predepositing APP23 mice (Fig. $3 B$ ) or due to the reduced aggregation propensity of this extended version of $\mathrm{A} \beta$. To this end, we measured the ability of brain homogenates to induce fibril formation of monomeric $A \beta$. $A \beta$ e and $A \beta$ eGPI extracts were compared with normal brain-derived $A \beta$ in vitro in the presence of Thioflavin $\mathrm{T}$ and recombinant $\mathrm{A} \beta 1-40$. (Fig. $3 E, F$ ). $\mathrm{A} \beta$ fibrils quantitatively detected by Thioflavin $\mathrm{T}$ incorporation spontaneously formed after passing a lag phase during which initial fibril seeds need to form. The addition of extracts containing aggregates suitable to seed $\mathrm{A} \beta$ fibrillization led to a reduced lag time until maximal fluorescence was reached. This effect was clearly seen when comparing lag times from young APP23 brains before
$\mathrm{A} \beta$ deposition to aged $\mathrm{A} \beta$ plaque-laden brains (curves of a representative extract are shown in Fig. $3 E$ ). Interestingly, A $\beta$ eGPI transgenic extracts from young mice already showed a slightly reduced lag time, although they contain significantly less $A \beta$ than young APP23 brains (Fig. 3C). The lag time was further decreased at old age, indicating that more A $\beta$ eGPI acquires seed structure during aging of the mice. A small effect was also found for $A \beta e$. Neither $A \beta$ eGPI nor $A \beta e$ extracts showed a prolonged lag time compared with nontransgenic extracts, excluding a negative influence on $\mathrm{A} \beta$ fibrillization. A combination of data from different mice showed the same effects (Fig. $3 F$ ) but due to variation significance was only reached for the APP23 extract.

\section{A $\beta$ eGPI accelerates plaque pathology of A $\beta$-depositing APP23 mice}

To examine whether the enhancement of fibrillization in vitro could be translated in vivo, we crossbred tg APP 23 with A $\beta$ eGPI mice. A $\beta$ e mice crossed with tg APP23 mice served as a control. Similar to the in vitro fibrillization experiment, there are three possible experimental outcomes. First, $\mathrm{A} \beta \mathrm{e}$ and $\mathrm{A} \beta \mathrm{eGPI}$ do not form appropriate $A \beta$ seeds, and will not interact with $A \beta$ from APP23 mice. Therefore, the coexpressing mice would be similar to single tg APP23 mice. Second, both A $\beta$ e and A $\beta$ eGPI could impede rather than promote $\beta$-amyloidosis in APP23 mice through cross-inhibition of amyloid formation (Eisenberg and 
A

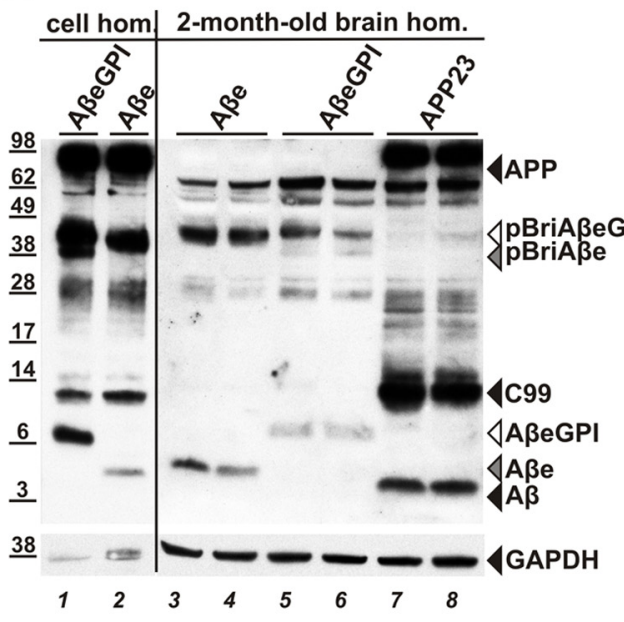

D
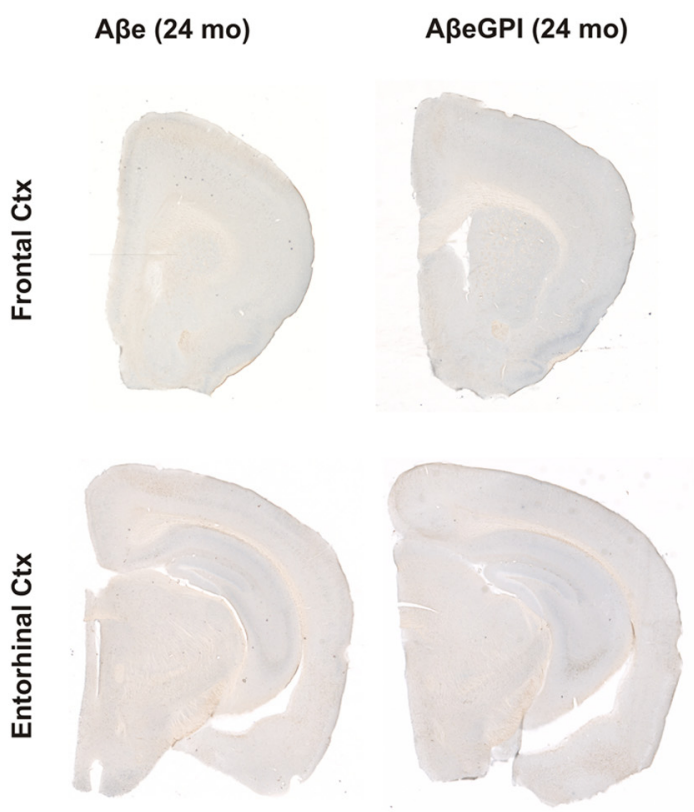

B

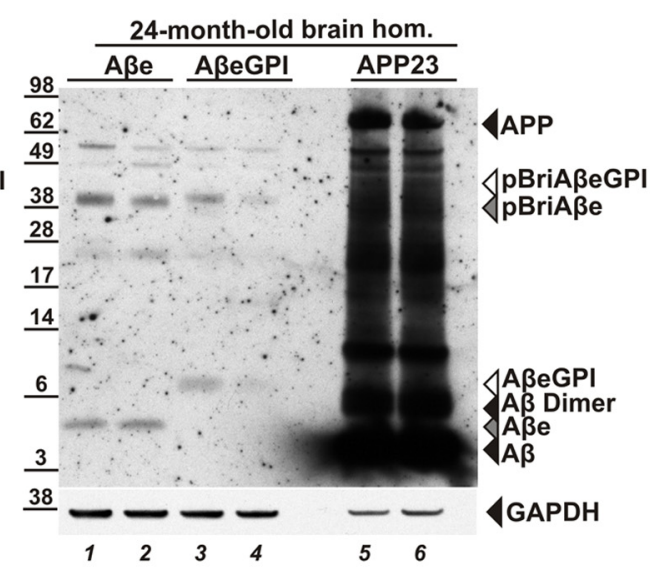

C

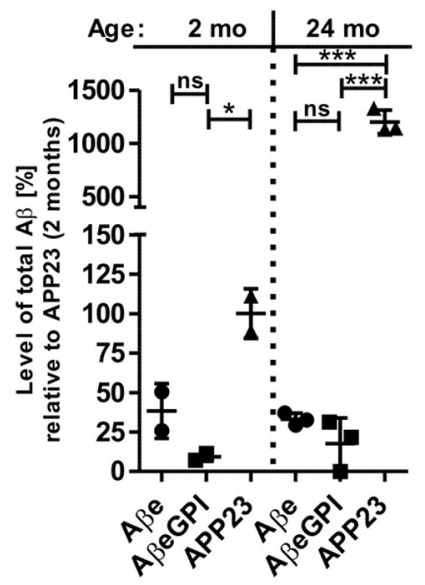

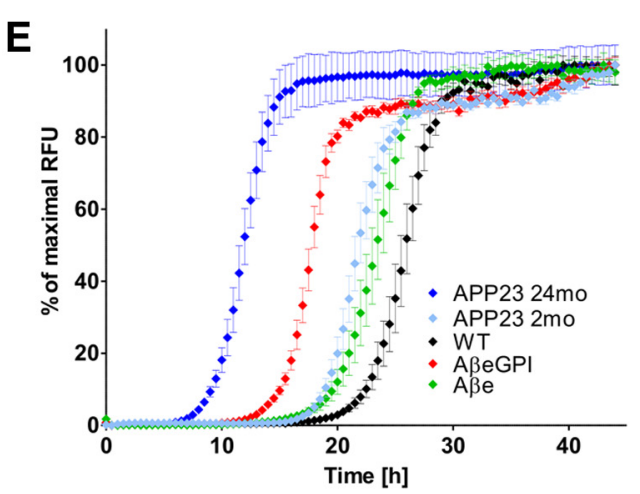

APP23 (16 mo)
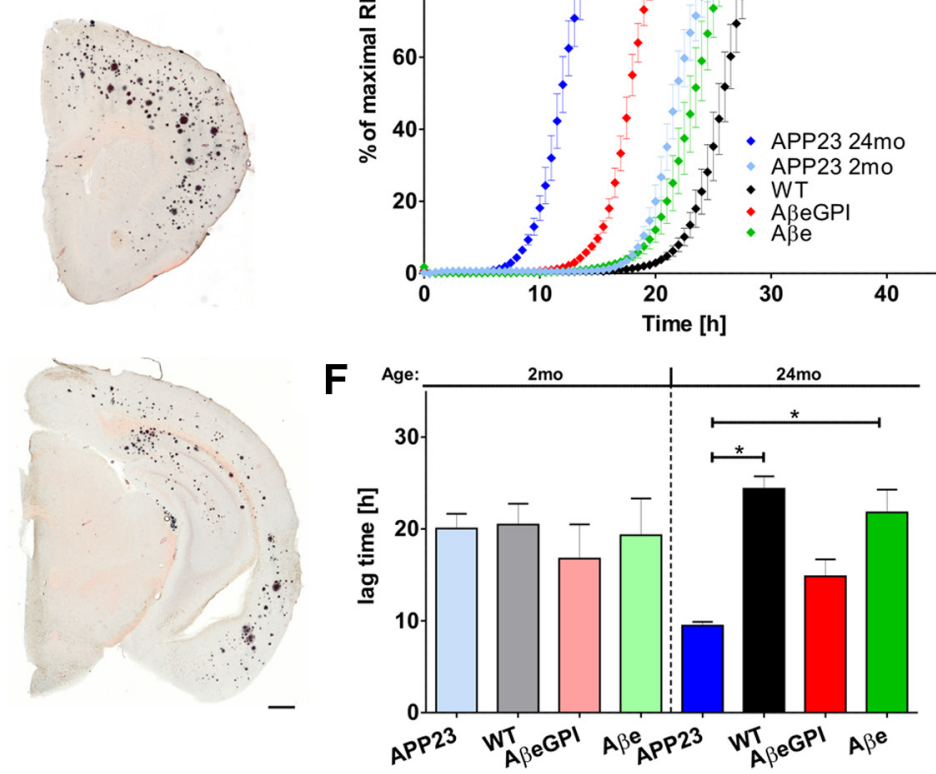

Figure 3. $p B r i A \beta e G P I$ and pBriA $\beta$ e undergo proteolytic processing, but, although tg mice do not show plaques, both promote $A \beta$ fibrillization. $A$, Western blot analysis of expression levels of HEK A $\beta$ eGPI (lane 1) and HEK A $\beta$ e (lane 2) cells (cell hom.), compared with brain extracts (brain hom.) from 2-month-old tg A $\beta$ e (lane 3, 4), A $\beta$ eGPI (lane 5, 6), and APP23 mice (lane 7, 8) with A $\beta$ antibody 6E10. B, Western blot analysis of brain extracts from 24-month-old tg A $\beta$ e (lane 1, 2), A $\beta$ eGPI (lane 3, 4), and APP23 (lane 5, 6) mice. C, Quantification of Western blots comparing the total expression levels of $A \beta$ e and $A \beta e G P I$ to $A \beta(100 \%)$ as a percentage in 2- and 24-month-old tg $A \beta e, A \beta e G P I$, and $A P P 23$ mice. $A \beta$ e and $A \beta$ eGPl are significantly lower expressed than $A \beta$ in 2-month-old tg APP23 mice (100\%) and stay merely unchanged at 24 month in contrast to 24-month-old tg APP23 mice ( 1200\%). There are significant differences between the groups, as indicated ( $n=2$ mice per group for all 2-month-old tg mice, and $n=3$ mice per group in all 24-month-old tg mice; ${ }^{*} p<0.05,{ }^{* * *} p<0.001$; ns, not significant, one-way ANOVA, Bonferroni's post hoc test for multiple comparisons). $D$, Histological analysis of 24-month-old tg A $\beta$ e and A $\beta$ eGPI mice. Coronal sections of respective tg lines through the frontal and entorhinal cortex stained with $A \beta$ antibody CN3 and Congo red. Amyloid deposition was observed in neither tg A $\beta$ e nor A $A$ eGPI mice. APP23 mice at the age of 16 months served as positive control of amyloid deposition. Scale bar, $500 \mu \mathrm{m}$. E, Fibrillization of recombinant $A \beta 1-40$ was monitored by incorporation of Thioflavin T. Kinetics are displayed as time versus relative fluorescence. Data points represent the mean and SE of eight technical replicates of a representative individual mouse of the indicated genotype. Brain homogenates containing fibrillization seeds reduced the lag phase until there is a steep fluorescence increase to reach plateau. $\boldsymbol{F}$, Comparison of lag times extracted from $\boldsymbol{E}$. At the age of 24 months, APP23 containing A $\beta$ plaques as well as A $\beta$ eGPI had reduced lag times compared with age-matched WT mice. Significant differences are only found between the groups indicated $\left({ }^{*} p<0.05\right.$, one-way ANOVA, Bonferroni's post hoc test for multiple comparisons; 2 -month-old APP23 mice, $n=4$; 2-month-old WT mice, $n=3 ; 2$-month-old A $\beta$ eGPI mice, $n=4 ; 2$-month-old A $\beta$ e mice, $n=4 ; 24$-month-old APP23 mice, $n=2 ; 24$-month-old WT mice, $n=2 ; 24$-month-old A $\beta$ eGPI mice, $n=4 ; 24$-month-old A $\beta$ e mice, $n=6$ ).

Jucker, 2012). Third, $A \beta e$ and $A \beta e G P I$ act as $A \beta$ seeds in the APP23 mice and enhance plaque formation.

Double tg A $\beta$ eGPI $\times$ APP23, A $\beta$ e $\times$ APP23, and single tg APP23 littermate controls were analyzed at 9 months of age (Fig. 4). Western blot analysis of brain extracts revealed a strong accumulation of APP23-derived $\mathrm{A} \beta$ in double tg A $\beta$ eGPI $\times$ APP23 and $\mathrm{A} \beta \mathrm{e} \times \mathrm{APP} 23$ mice. In contrast, age-matched single tg APP23 littermates showed only very modest $\mathrm{A} \beta$ accumulation. Notably, double tg A $\beta$ eGPI $\times$ APP23 mice accumulated more $\mathrm{A} \beta$ than double tg $\mathrm{A} \beta \mathrm{e} \times \mathrm{APP} 23$ mice, resembling the amounts of aggregated $\mathrm{A} \beta$ in 14-month-old single tg APP23 mice (Fig. $4 A)$. The levels of aggregated $\mathrm{A} \beta$ resistant to $\mathrm{PK}$ treatment 
A

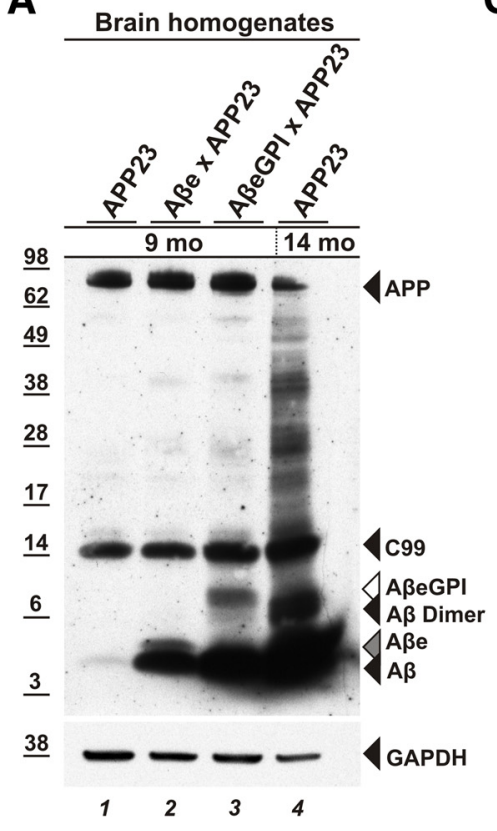

C

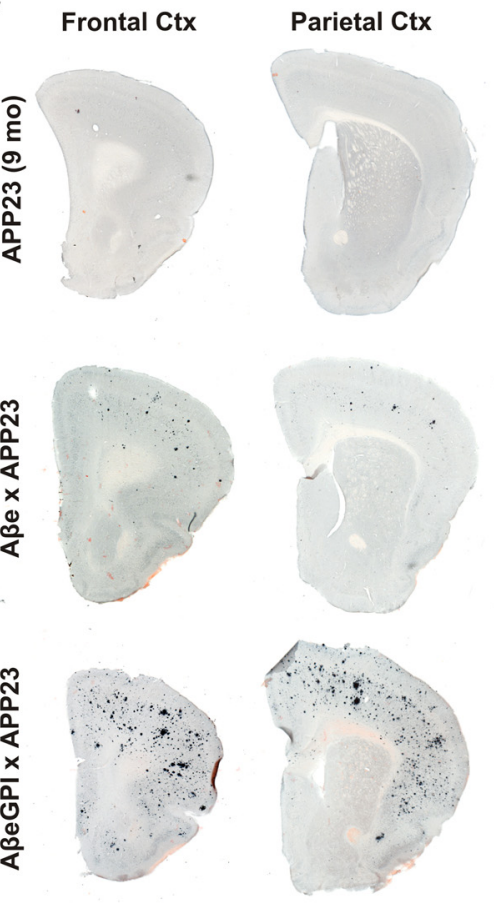

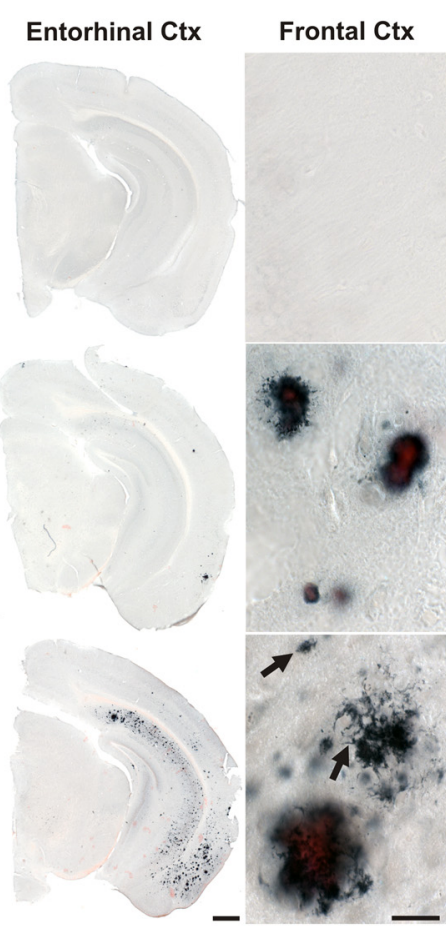
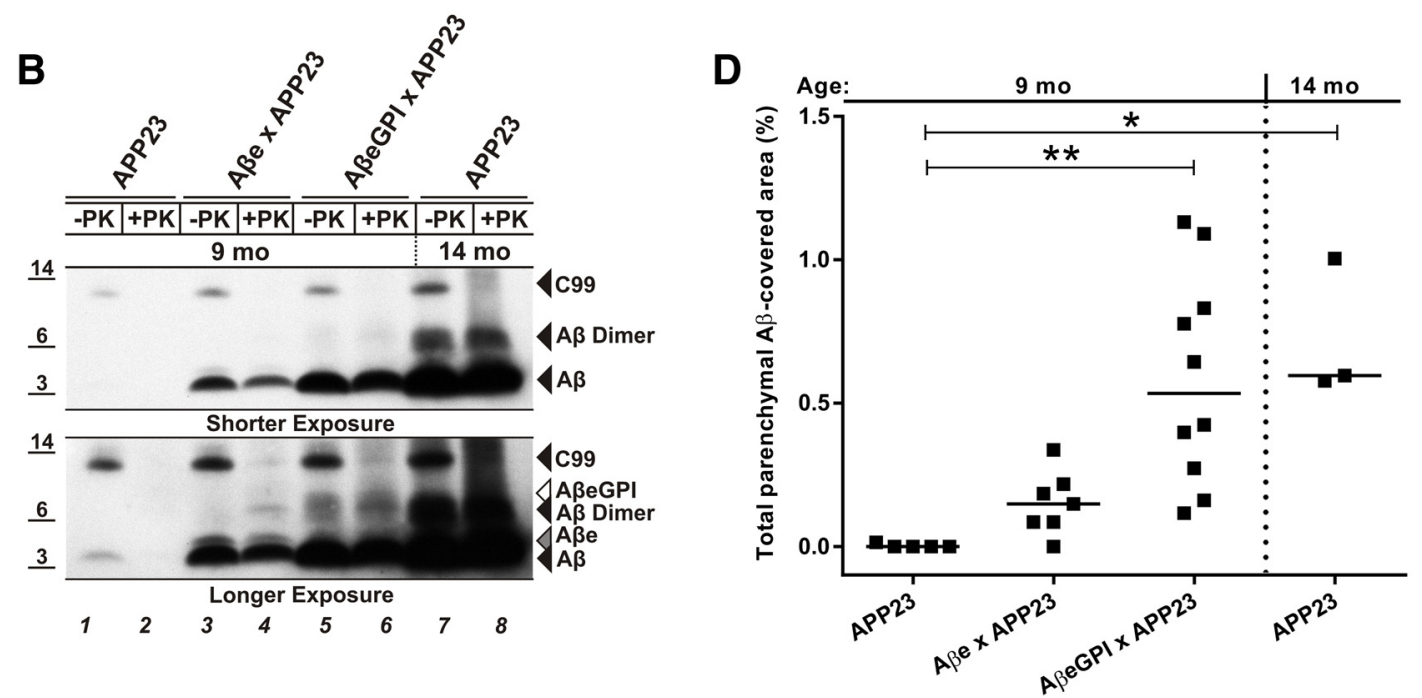

Figure 4. Membrane-anchored A $\beta$ eGPI accelerates accumulation of A $\beta$ in APP23 mice and leads to both congophilic and noncongophilic $A \beta$ deposits. $A$, Western blot analysis of brain extracts from 9-month-old single tg APP23, double tg A $\beta$ e $\times$ APP23, A $\beta$ eGPI $\times A P P 23$, and 14-month-old single tg APP23 mice, with A $\beta$ antibody 6E10. The A $\beta$ level of 9-month-old single tg APP23 mice (lane 1) is extremely low in contrast to $A \beta$ levels in double tg mice (lanes 2,3), resembling the status of single tg APP23 mice at 14 months of age (lane 4). $\boldsymbol{B}$, Brain extracts, as in $\boldsymbol{A}$, were treated with $100 \mu \mathrm{g} / \mathrm{ml}$ proteinase K (+PK) and were analyzed with Western blot using 6E10. A $\beta$ (lanes 4, 6, 8), A $\beta$ e (lane 4), and A $\beta$ eGPI (lane 6) in the respective tg mice were PK resistant. Protease-sensitive APP-derived (99 fragment serves as an internal control for the efficacy of the PK treatment. C, Coronal sections through the cortex of respective tg lines at 9 months of age costained with A $\beta$ antibody CN3 and Congo red. APP23 mice only show one to three plaques in the frontal cortex; in the double tg A $\beta$ e $\times$ APP23 mice, few plaque deposits are visible, while double tg A $\beta$ eGPI $\times$ APP23 mice show robust plaque formation. Scale bar, $500 \mu \mathrm{m}$. Double tg mice displayed a plaque morphology, which is not seen in single tg APP23 mice at 9 months. Amorphous noncongophilic deposits were exclusively seen in double tg A $\beta$ eGPI $\times$ APP23 mice (arrows). Scale bar, $50 \mu \mathrm{m}$. D, Stereological quantification of $\boldsymbol{C}$, with significant differences between medians of the groups as indicated $(n=$ 5 for APP23, $n=7$ for A $\beta$ e $\times$ APP23, $n=10$ for A $\beta$ eGPI $\times$ APP23, $n=3$ mice in the group of APP23 tg mice at 14 months of age; ${ }^{*} p<0.05,{ }^{* *} p<0.01$, Kruskal-Wallis nonparametric ANOVA with Dunn's multiple-comparisons test).

(Langer et al., 2011) were consistently higher in the double tg $\mathrm{A} \beta \mathrm{eGPI} \times \mathrm{APP} 23$ mice followed by the $\operatorname{tg} \mathrm{A} \beta \mathrm{e} \times \mathrm{APP} 23$ and then single tg APP23 mice (Fig. 4B).

Consistent with the biochemical analysis, immunohistological examination of mice brain sections demonstrated enhanced plaque formation in double tg A $\beta$ eGPI $\times$ APP23 when compared with APP23 and A $\beta$ e $\times$ APP23 animals (Fig. 4C,D). Deposits were predominantly found in the frontal, parietal, and entorhinal cortices as well as the hippocampus (Fig. 4C). Notably, the amyloid deposition in 9-month-old double tg A $\beta$ eGPI $\times$ APP23 mice resembled the amyloid load encountered in 14-month-old single tg APP23 mice. In contrast, the 9-month-old tg APP23 littermates were still at the initial phase of deposition with one to three plaques in the frontal cortex, quantitatively confirmed by stereological analysis (adjusted $p$ values of Dunn's multiple-comparisons test: 9-month-old APP23 vs $\mathrm{A} \beta \mathrm{e} \times \mathrm{APP} 23$ mice, $p=0.9265$; 9-month-old APP23 vs A $\beta \mathrm{eGPI} \times$ 
APP23 mice, $p=0.0022$; 9-month-old APP23 vs 14-month-old $\mathrm{APP} 23$ mice, $p=0.0132$; $\mathrm{A} \beta \mathrm{e} \times \mathrm{APP} 23$ vs $\mathrm{A} \beta \mathrm{eGPI} \times \mathrm{APP} 23, p=$ $0.1411 ; \mathrm{A} \beta \mathrm{e} \times \mathrm{APP} 23$ vs 14 -month-old APP23, $p=0.2526$; $\mathrm{A} \beta \mathrm{eGPI} \times \mathrm{APP} 23$ vs 14 -month-old APP23, $p>0.9999$; Fig. $4 D)$. Despite the lower expression level of $A \beta e G P I$ compared with $A \beta e$, double tg A $\beta$ eGPI $\times$ APP23 mice developed more plaques than double tg A $\beta \mathrm{e} \times \mathrm{APP} 23$ mice. The majority of the $\mathrm{A} \beta$ deposits were congophilic in the double tg mice (Fig. 4C). However, A $\beta$ eGPI $\times$ APP23 mice also displayed amorphous Congo red-negative deposits (Fig. 4C).

\section{GPI-anchored A $\boldsymbol{\beta}$ exacerbates neurotoxicity}

Histological analysis of neurotoxicity indicated a displacement of neurons in the vicinity of plaques in the stratum granulosum of the dentate gyrus and CA1 stratum pyramidal of the hippocampus in 9-month-old double tg A $\beta$ eGPI $\times$ APP23 mice, which was not found in the control mice (Fig. 5A). Moreover, dystrophic boutons and hyperphosphorylated tau-positive neuritic elements appeared to be increased in double tg A $\beta$ eGPI $\times$ APP23 mice when compared with double tg A $\beta \mathrm{e} \times \mathrm{APP} 23$ mice (Fig. $5 A$ ). It is important to note that even synaptic and neuritic abnormalities were found around the Congo red-negative amorphous $\mathrm{A} \beta$ deposits in the A $\beta$ eGPI $\times$ APP23 animals (Fig. $5 A$ ). Activation of astrocytes and microglia was detected around all congophilic $\mathrm{A} \beta$ deposits in both double tg A $\beta \mathrm{e} \times \mathrm{APP} 23$ and A $\beta \mathrm{eGPI} \times \mathrm{APP} 23$ mice (Fig. 5A). However, the inflammatory reaction in A $\beta$ GPI $\times$ APP23 mice was significantly higher than in all other age-matched mice and resembled aged tg APP23 mice (SturchlerPierrat et al., 1997). Further analysis with electron microscopy revealed no evidence for morphological changes of membrane architecture in response to membrane anchoring (data not shown).

PK treatment of DRM fractions prepared from the different mice revealed PK-resistant $\mathrm{A} \beta, \mathrm{A} \beta \mathrm{e}$, and $\mathrm{A} \beta \mathrm{eGPI}$ in the DRM fractions (Fig. $5 A, B$ ). Interestingly, the highest amount of PKresistant DRM material was found in the double tg A $\beta$ eGPI $\times$ APP23 mice. This finding suggests that, in addition to increased levels of $\mathrm{A} \beta$ deposition, $\mathrm{A} \beta \mathrm{eGPI} \times \mathrm{APP} 23$ mice have more membrane-associated $A \beta$ aggregates, which have been suspected to cause neurotoxicity (Rushworth and Hooper, 2010).

\section{Discussion}

This study provides in vivo evidence for the participation of membrane-associated $\mathrm{A} \beta_{42}$ peptide in promoting $\mathrm{A} \beta$ aggregation and neurotoxicity. To this end, a novel tg mouse model expressing artificially $\mathrm{A} \beta \mathrm{eGPI}$ on the membrane surface of neurons was generated. To exclude concerns that modifications at the $\mathrm{C}$ terminus of the $\mathrm{A} \beta_{42}$ peptide might interfere with the aggregation abilities of $A \beta$, we devised an extended form of secreted $\mathrm{A} \beta(\mathrm{A} \beta \mathrm{e})$ consisting of amino acid residues identical to $\mathrm{A} \beta \mathrm{eGPI}$, but without the GPI anchor.

The influence of biological membranes on protein aggregation has been described from in vitro studies using a variety of disease-associated, proteopathic proteins such as $\mathrm{A} \beta, \alpha$-synuclein, and PrP (Yip et al., 2001; Kazlauskaite et al., 2003; Zhu et al., 2003; Bokvist et al., 2004). More recently, a common phenomenon, known as "macromolecular crowding" has been described in which membranes locally concentrate proteins (Bokvist and Gröbner, 2007). Local protein accumulation has been shown to promote the conversion of $\mathrm{A} \beta$ and $\operatorname{PrP}$ to $\beta$-sheet-rich structures (Wang et al., 2007; Byström et al., 2008). Lipid rafts, which essentially are a membranous subcompartment, have thus received increased attention in $\mathrm{AD}$ and prion disease research. PrP, the fundamental component of prion infectivity, is GPI anchored and therefore a raft protein (Vey et al., 1996). APP, the source for ADlinked $\mathrm{A} \beta$ peptide, is proteolytically processed by $\beta$ - and $\gamma$-secretase, a process reported to be raft associated (for review, see Rushworth and Hooper, 2010). Furthermore, lipid raft fractions isolated from human $\mathrm{AD}$ brains and transgenic mouse models showed high amounts of $A \beta$ dimers (Kawarabayashi et al., 2004), and main components of lipid rafts have been found to be associated with amyloid fibrils, pointing to a common cellular mechanism of amyloid formation (Gellermann et al., 2005). Therefore, lipid rafts may be sites of enhanced $\mathrm{A} \beta$ aggregation and are important in $\mathrm{AD}$ pathogenesis.

In the present study, $\mathrm{A} \beta$ was linked to membranes via the $\operatorname{PrP}$ GPI anchor. This strategy was used for several reasons, as follows: (1) GPI is known to direct proteins to DRMs, resulting in higher local concentrations of the GPI-linked peptide, which might assist in the initial steps of oligomerization; (2) GPI is a very flexible domain that provides a higher degree of rotational and bending freedom for the anchored protein than a classical transmembrane domain, and this flexibility might be crucial for $\mathrm{A} \beta$ oligomerization; (3) GPI-anchored proteins can easily be shed, if membrane release is required for further $A \beta$ aggregation (Borchelt et al., 1993); and (4) DRMs are found to be present in exosomes, which have already been suspected to play a role in neurodegenerative diseases like AD (Rajendran et al., 2006; Ghidoni et al., 2008; Sharples et al., 2008).

First, we used cell culture models to provide evidence that $\mathrm{A} \beta_{42}$ can be stably expressed on membrane surfaces via a GPI anchor, and that membrane-anchored $\mathrm{A} \beta_{42}$ localizes to DRMs. Cytotoxicity was not observed when $\mathrm{A} \beta \mathrm{eGPI}$ was expressed in HEK cells. This could be due to the rapid internalization of available membrane surface A $\beta$ eGPI by the cell, a process also described for PrP (Rieger et al., 1997). Moreover, it has also been reported that neuronal cell lines (e.g., N2A and PC12 cells) chronically replicate infectious prions but lack a cytotoxic phenotype (Rubenstein et al., 1984; Race et al., 1987; Bosque and Prusiner, 2000; Klöhn et al., 2003).

To investigate the consequences of $\mathrm{A} \beta \mathrm{e}$ and $\mathrm{A} \beta \mathrm{eGPI}$ expression on neurons in vivo, Thyl promoter-driven transgenic mice were generated. The levels of $\mathrm{A} \beta \mathrm{e}$ and $\mathrm{A} \beta \mathrm{eGPI}$ in the mice reached only a fraction of the A $\beta$ levels present in APP23 mice, which use the same Thyl promoter element. Even at 24 months of age, both $\mathrm{A} \beta \mathrm{e}$ and A $\beta$ eGPI tg mouse lines displayed no spontaneous $A \beta$ deposition. This suggests that the critical threshold for spontaneous aggregation was not reached in the single tg $A \beta e$ and $A \beta e G P I$ mice. Such a dose-dependent phenomenon has been reported for PrP. Depending on expression levels, mice overexpressing anchorless PrP spontaneously deposit PrP plaques even in the absence of an infectious seed, while mice with a lower expression level deposited PrP only after prion inoculation (Chesebro et al., 2005, 2010; Stöhr et al., 2011).

To study the amyloidogenicity of the membrane-bound $\mathrm{A} \beta$ peptides, we crossed single tg A $\beta$ eGPI and A $\beta$ e mice with APP23 mice, and analyzed $\mathrm{A} \beta$ plaque deposition at the age of 9 months. Amyloid formation depends on sufficient available soluble $\mathrm{A} \beta$ and $A \beta$ seeds (Harper and Lansbury, 1997). If the C-terminal extension of $\mathrm{A} \beta$ had interfered with the amyloid formation in the double tg mice, the onset of $\mathrm{A} \beta$ deposition would have been delayed (Eisenberg and Jucker, 2012). However, A $\beta$ plaque deposition in double tg mice was found to be increased when compared with APP23 tg mice. A previous study has shown that plaque-depositing transgenic mice contain PK-resistant $\mathrm{A} \beta$ species (Langer et al., 2011). Consistently, PK resistance was also found in the $\mathrm{A} \beta \mathrm{eGPI} \times \mathrm{APP} 23$ and $\mathrm{A} \beta \mathrm{e} \times \mathrm{APP} 23$ mice, indicat- 
A

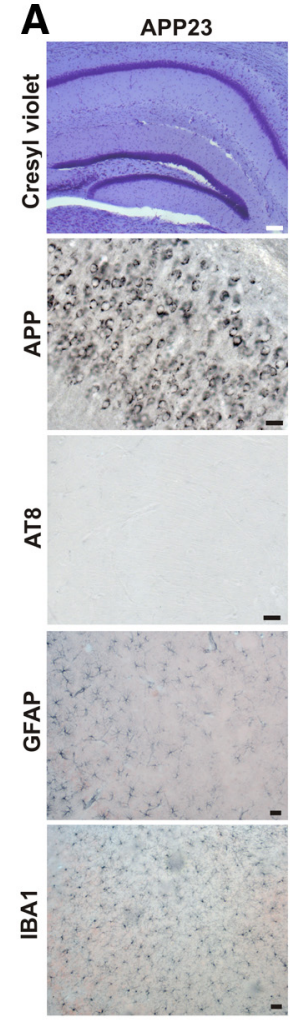

B

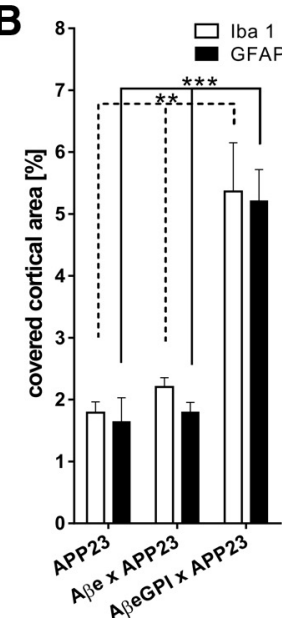

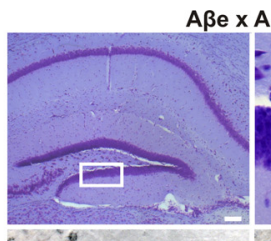

Aße $\times$ APP23
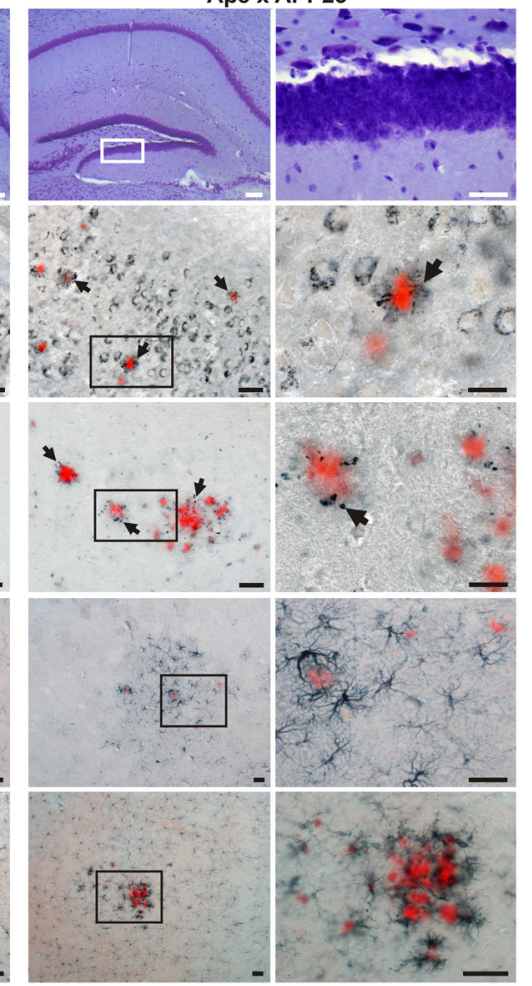

C

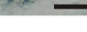

Top 4

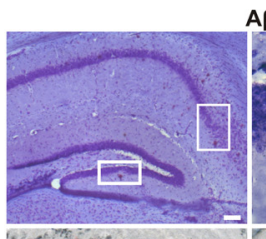

AßeGPI x APP23
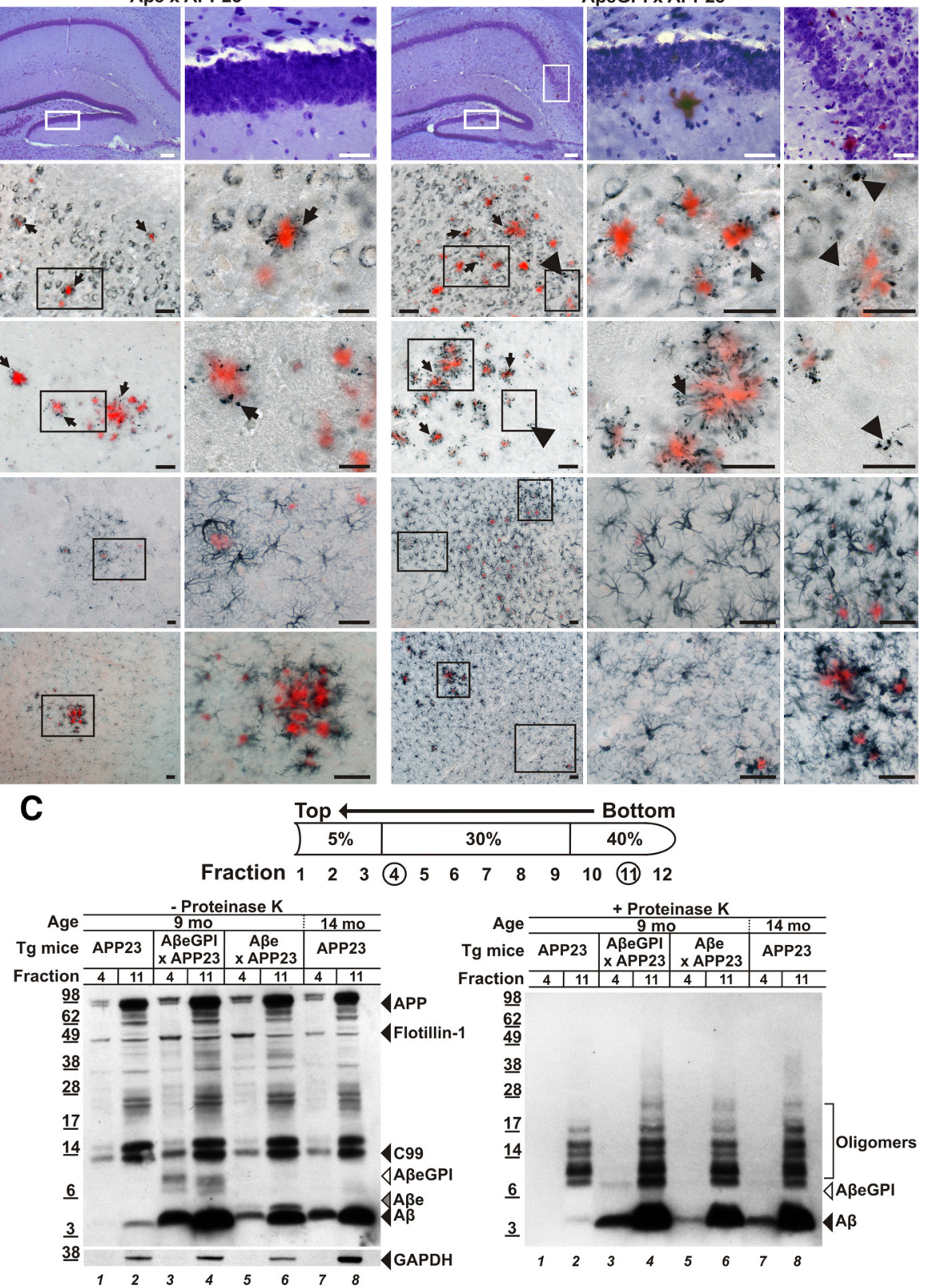

Figure 5. A $A$ eGPI exacerbates amyloid-associated toxicity and promotes localization of aggregated $A \beta$ species in DRM. $A$, Degenerative processes in double tg A $\beta$ e $\times A P P 23$ and $A \beta$ eGPI $\times$ APP23 mice. Hippocampal brain sections of 9-month-old tg mice stained with cresyl violet, anti-APP, anti-Tau (AT8), GFAP, and lba1, respectively. All sections were additionally stained with Congo red. Higher magnifications for the double tg mice are shown in the right columns. In double tg A $\beta$ eGPI $\times$ APP23 mice, displaced neurons and neuron loss are found at the sites of plaque deposition in neuronal loss at the stratum granulosum of the dentate gyrus and the CA1 stratum pyramidale of the hippocampus. Both double tg mice show dystrophic APP-positive synaptic boutons (arrows) and AT8-positive neuritic structures (arrows) in proximity to congophilic plaques. In addition, in the A $\beta$ GPI $\times$ APP23 mice APP-positive and AT8-positive dystrophic structures are found in vicinity of amorphous and Congo red-negative $A \beta$ deposits (arrowheads). Both double tg lines display activations of astrocytes and microglia. However, in the A $\beta e G P I \times A P P 23$ mice additional activated glia cell are found that are not restricted to the direct proximity of the congophilic deposits. Scale bar, $40 \mu \mathrm{m}$. $\boldsymbol{B}$, Morphometric analysis revealed a significant increase of the area covered by Iba1 and GFAP staining in double tg A $\beta$ eGPI $\times$ APP23 mice compared with A $\beta$ e $\times$ APP23 and APP23 mice $\left(n=5\right.$ for APP23, $n=7$ for A $\beta$ e $\times$ APP23, $n=10$ for A $\beta$ eGPI $\times$ APP23; ${ }^{* *} p<0.01$, ${ }^{* * *} p<$ 0.001, one-way ANOVA Bonferroni's post hoc test for multiple comparisons). C, Left DRM extraction from brain homogenate treated with cold Triton X-100, followed by OptiPrep step density gradient. DRM proteins (fraction 4) and total protein load (fraction 11) were compared in 9-month-old tg APP23, double tg A BeGPI $\times$ APP23, A e $\times$ APP23, and 14-month-old tg APP23 mice by Western blot probed with 6E10. A $\beta$ is present in all DRM fractions except for the 9-month-old APP23 predepositing mice (lanes 1 and 2). Flotillin-1 marker for DRMs; GAPDH marker for cytoplasmic protein. Right, Fractions from left treated with $100 \mu \mathrm{g} / \mathrm{ml}$ proteinase $\mathrm{K}$ (+PK) for $30 \mathrm{~min}$ and analyzed by Western blot probed with A $\beta$ antibody 6 E 10 . DRM-associated A $\beta$ of respective tg mice (lanes 3, 5, and 7) displayed PK resistance.

ing that the extended versions $\mathrm{A} \beta \mathrm{eGPI}$ and $\mathrm{A} \beta \mathrm{e}$ acquired the amyloidogenic state, and were amyloid competent similar to the $\mathrm{A} \beta$ derived from tg APP23 mice. This observation resembles the interaction between anchorless and GPI-anchored PrP for the prion pathogenesis (Chesebro et al., 2005).
Both $\mathrm{A} \beta \mathrm{eGPI} \times \mathrm{APP} 23$ and $\mathrm{A} \beta \mathrm{e} \times \mathrm{APP} 23$ tg mouse lines developed more amyloid lesions than age-matched single tg APP23 littermates, suggesting that the process of deposition starts earlier. However, despite the higher steady-state levels of $\mathrm{A} \beta \mathrm{e}$ compared with $\mathrm{A} \beta \mathrm{eGPI}$ in the respective mice, $\mathrm{A} \beta \mathrm{eGPI}$ was 
more efficient in promoting $\mathrm{A} \beta$ accumulation and plaque formation. The accelerated plaque formation in A $\beta$ GGPI $\times$ APP 23 mice indicates that the tethering of $A \beta e G P I$ to DRMs by the GPI anchor provided a better nucleus for $A \beta$ aggregation than soluble $\mathrm{A} \beta \mathrm{e}$, which resulted in recruiting more $\mathrm{A} \beta$. This is also consistent with the finding that $A \beta e G P I$ showed a high propensity to induce $\mathrm{A} \beta$ fibrillization in vitro even at a young age.

Double tg A $\beta e G P I \times A P P 23$ and A $\beta e \times$ APP23 mice differed in amyloid morphotypes and neurotoxicity. Amorphous Congo red-negative deposits were observed only in A $\beta$ eGPI $\times$ APP23 mice, not in age-matched $\mathrm{A} \beta \mathrm{e} \times \mathrm{APP} 23$ mice, and are likely the result of the $A \beta$ attachment to the membrane. Congophilic, but also amorphous, deposits were surrounded by neuritic hyperphosphorylated tau-positive structures and dystrophic boutons. The inflammatory response whose controversial role in $\mathrm{AD}$ has been discussed before (for review, see Guillot-Sestier and Town, 2013) was significantly higher in A $\beta$ eGPI $\times$ APP23 double transgenic mice. Activation of astrocytes and microglia was not restricted to direct proximity of congophilic deposits. It was completely absent in both single transgenic $\mathrm{A} \beta \mathrm{e}$ and $\mathrm{A} \beta \mathrm{eGPI}$ mice. These observations are reminiscent to the distinct plaque morphology of specific prion strains with or without PrP membrane attachment. For example, the Rocky Mountain Laboratories (RML) prion strain normally deposits in wild-type mice only diffusely, with no defined plaque deposits inducing clinical signs of disease and causing lethality. When the same RML inoculation strain is replicating in a mouse with anchorless $\operatorname{PrP}$, the mice develop large congophilic plaques but lack a clinical phenotype (Chesebro et al., 2005). Thus, $\mathrm{A} \beta$ attachment to the membrane and its localization in DRMs might be a prerequisite for its neurotoxic abilities, similar to prion disease. Up to 15 months of age, none of the A $\beta$ eGPI $\times$ APP23 mice displayed a lethal phenotype. However, one cannot exclude that a lethal phenotype will occur with further aging of the mice or at higher expression levels of the A $\beta$ eGPI construct.

In conclusion, the membrane-anchored $\mathrm{A} \beta$ mouse model described here demonstrates in vivo that lipid membranes facilitate the conversion of $A \beta$ to aggregated, amyloid-seeding $A \beta$ species and exacerbate amyloid-associated toxicity. Thus, $A \beta$-membrane interactions may play a pivotal role in the onset of $\mathrm{AD}$ pathogenesis and provide a new therapeutic target, which can now be experimentally tested.

\section{References}

Andrä K, Abramowski D, Duke M, Probst A, Wiederhold KH, Bürki K, Goedert M, Sommer B, Staufenbiel M (1996) Expression of APP in transgenic mice: a comparison of neuron-specific promoters. Neurobiol Aging 17:183-190. CrossRef Medline

Baumann F, Tolnay M, Brabeck C, Pahnke J, Kloz U, Niemann HH, Heikenwalder M, Rülicke T, Bürkle A, Aguzzi A (2007) Lethal recessive myelin toxicity of prion protein lacking its central domain. EMBO J 26:538-547. CrossRef Medline

Baumann F, Pahnke J, Radovanovic I, Rülicke T, Bremer J, Tolnay M, Aguzzi A (2009) Functionally relevant domains of the prion protein identified in vivo. PLoS One 4:e6707. CrossRef Medline

Bokvist M, Gröbner G (2007) Misfolding of amyloidogenic proteins at membrane surfaces: the impact of macromolecular crowding. J Am Chem Soc 129:14848-14849. CrossRef Medline

Bokvist M, Lindström F, Watts A, Gröbner G (2004) Two types of Alzheimer's beta-amyloid (1-40) peptide membrane interactions: aggregation preventing transmembrane anchoring versus accelerated surface fibril formation. J Mol Biol 335:1039-1049. CrossRef Medline

Borchelt DR, Rogers M, Stahl N, Telling G, Prusiner SB (1993) Release of the cellular prion protein from cultured cells after loss of its glycoinositol phospholipid anchor. Glycobiology 3:319-329. CrossRef Medline
Bosque PJ, Prusiner SB (2000) Cultured cell sublines highly susceptible to prion infection. J Virol 74:4377-4386. CrossRef Medline

Byström R, Aisenbrey C, Borowik T, Bokvist M, Lindström F, Sani MA, Olofsson A, Gröbner G (2008) Disordered proteins: biological membranes as two-dimensional aggregation matrices. Cell Biochem Biophys 52:175-189. CrossRef Medline

Calhoun ME, Wiederhold KH, Abramowski D, Phinney AL, Probst A, Sturchler-Pierrat C, Staufenbiel M, Sommer B, Jucker M (1998) Neuron loss in APP transgenic mice. Nature 395:755-756. CrossRef Medline

Chesebro B, Trifilo M, Race R, Meade-White K, Teng C, LaCasse R, Raymond L, Favara C, Baron G, Priola S, Caughey B, Masliah E, Oldstone M (2005) Anchorless prion protein results in infectious amyloid disease without clinical scrapie. Science 308:1435-1439. CrossRef Medline

Chesebro B, Race B, Meade-White K, Lacasse R, Race R, Klingeborn M, Striebel J, Dorward D, McGovern G, Jeffrey M (2010) Fatal transmissible amyloid encephalopathy: a new type of prion disease associated with lack of prion protein membrane anchoring. PLoS Pathog 6:e1000800. CrossRef Medline

Chi EY, Ege C, Winans A, Majewski J, Wu G, Kjaer K, Lee KY (2008) Lipid membrane templates the ordering and induces the fibrillogenesis of Alzheimer's disease amyloid-beta peptide. Proteins 72:1-24. CrossRef Medline

Colby DW, Zhang Q, Wang S, Groth D, Legname G, Riesner D, Prusiner SB (2007) Prion detection by an amyloid seeding assay. Proc Natl Acad Sci U S A 104:20914-20919. CrossRef Medline

Eisele YS, Obermüller U, Heilbronner G, Baumann F, Kaeser SA, Wolburg H, Walker LC, Staufenbiel M, Heikenwalder M, Jucker M (2010) Peripherally applied Abeta-containing inoculates induce cerebral betaamyloidosis. Science 330:980-982. CrossRef Medline

Eisenberg D, Jucker M (2012) The amyloid state of proteins in human diseases. Cell 148:1188-1203. CrossRef Medline

Fischer M, Rülicke T, Raeber A, Sailer A, Moser M, Oesch B, Brandner S, Aguzzi A, Weissmann C (1996) Prion protein (PrP) with aminoproximal deletions restoring susceptibility of PrP knockout mice to scrapie. EMBO J 15:1255-1264. Medline

Franklin KBJ, Paxinos G (2004) The Mouse Brain in Stereotaxic Coordinates. San Diego: Academic.

Gellermann GP, Appel TR, Tannert A, Radestock A, Hortschansky P, Schroeckh V, Leisner C, Lutkepohl T, Shtrasburg S, Röcken C, Pras M, Linke RP, Diekmann S, Fändrich M (2005) Raft lipids as common components of human extracellular amyloid fibrils. Proc Natl Acad Sci U S A 102:6297-6302. CrossRef Medline

Ghidoni R, Benussi L, Binetti G (2008) Exosomes: the Trojan horses of neurodegeneration. Med Hypotheses 70:1226-1227. CrossRef Medline

Guillot-Sestier MV, Town T (2013) Innate immunity in Alzheimer's disease: a complex affair. CNS and neurological disorders drug targets 12: 593-607. CrossRef Medline

Haass C, De Strooper B (1999) The presenilins in Alzheimer's diseaseproteolysis holds the key. Science 286:916-919. CrossRef Medline

Hardy J, Selkoe DJ (2002) The amyloid hypothesis of Alzheimer's disease: progress and problems on the road to therapeutics. Science 297:353-356. CrossRef Medline

Harper JD, Lansbury PT Jr (1997) Models of amyloid seeding in Alzheimer's disease and scrapie: mechanistic truths and physiological consequences of the time-dependent solubility of amyloid proteins. Annu Rev Biochem 66:385-407. CrossRef Medline

Kapur JN, Sahoo PK, Wong ACK (1985) A new method for gray-level picture thresholding using the entropy of the histogram. Graph Models Image Proc 29:273-285. CrossRef

Kawarabayashi T, Shoji M, Younkin LH, Wen-Lang L, Dickson DW, Murakami T, Matsubara E, Abe K, Ashe KH, Younkin SG (2004) Dimeric amyloid $\beta$ protein rapidly accumulates in lipid rafts followed by apolipoprotein $\mathrm{E}$ and phosphorylated tau accumulation in the $\mathrm{Tg} 2576$ mouse model of Alzheimer's disease. J Neurosci 24:3801-3809. CrossRef Medline

Kazlauskaite J, Sanghera N, Sylvester I, Vénien-Bryan C, Pinheiro TJ (2003) Structural changes of the prion protein in lipid membranes leading to aggregation and fibrillization. Biochemistry 42:3295-3304. CrossRef Medline

Klöhn PC, Stoltze L, Flechsig E, Enari M, Weissmann C (2003) A quantitative, highly sensitive cell-based infectivity assay for mouse scrapie prions. Proc Natl Acad Sci U S A 100:11666-11671. CrossRef Medline 
Langer F, Eisele YS, Fritschi SK, Staufenbiel M, Walker LC, Jucker M (2011) Soluble $\mathrm{A} \beta$ seeds are potent inducers of cerebral $\beta$-amyloid deposition. J Neurosci 31:14488-14495. CrossRef Medline

Lee SJ, Liyanage U, Bickel PE, Xia W, Lansbury PT Jr, Kosik KS (1998) A detergent-insoluble membrane compartment contains A beta in vivo. Nat Med 4:730-734. CrossRef Medline

Lewis PA, Piper S, Baker M, Onstead L, Murphy MP, Hardy J, Wang R, McGowan E, Golde TE (2001) Expression of BRI-amyloid beta peptide fusion proteins: a novel method for specific high-level expression of amyloid beta peptides. Biochim Biophys Acta 1537:58-62. CrossRef Medline

Lingwood D, Simons K (2007) Detergent resistance as a tool in membrane research. Nat Protoc 2:2159-2165. CrossRef Medline

Mathews PM, Jiang Y, Schmidt SD, Grbovic OM, Mercken M, Nixon RA (2002) Calpain activity regulates the cell surface distribution of amyloid precursor protein. Inhibition of calpains enhances endosomal generation of beta-cleaved C-terminal APP fragments. J Biol Chem 277:3641536424. CrossRef Medline

McGowan E, Pickford F, Kim J, Onstead L, Eriksen J, Yu C, Skipper L, Murphy MP, Beard J, Das P, Jansen K, Delucia M, Lin WL, Dolios G, Wang R, Eckman CB, Dickson DW, Hutton M, Hardy J, Golde T (2005) Abeta42 is essential for parenchymal and vascular amyloid deposition in mice. Neuron 47:191-199. CrossRef Medline

Naslavsky N, Stein R, Yanai A, Friedlander G, Taraboulos A (1997) Characterization of detergent-insoluble complexes containing the cellular prion protein and its scrapie isoform. J Biol Chem 272:6324-6331. CrossRef Medline

Nielsen L, Khurana R, Coats A, Frokjaer S, Brange J, Vyas S, Uversky VN, Fink AL (2001) Effect of environmental factors on the kinetics of insulin fibril formation: elucidation of the molecular mechanism. Biochemistry 40: 6036-6046. CrossRef Medline

Race RE, Fadness LH, Chesebro B (1987) Characterization of scrapie infection in mouse neuroblastoma cells. J Gen Virol 68:1391-1399. Medline

Rajendran L, Honsho M, Zahn TR, Keller P, Geiger KD, Verkade P, Simons K (2006) Alzheimer's disease beta-amyloid peptides are released in association with exosomes. Proc Natl Acad Sci U S A 103:11172-11177. CrossRef Medline

Rieger R, Edenhofer F, Lasmézas CI, Weiss S (1997) The human 37-kDa laminin receptor precursor interacts with the prion protein in eukaryotic cells. Nat Med 3:1383-1388. CrossRef Medline

Rubenstein R, Carp RI, Callahan SM (1984) In vitro replication of scrapie agent in a neuronal model: infection of PC12 cells. J Gen Virol 65:21912198. Medline

Rushworth JV, Hooper NM (2010) Lipid rafts: linking Alzheimer's amyloid-beta production, aggregation, and toxicity at neuronal membranes. Int J Alzheimers Dis 2011:603052. CrossRef Medline

Rutishauser D, Mertz KD, Moos R, Brunner E, Rülicke T, Calella AM, Aguzzi A (2009) The comprehensive native interactome of a fully functional tagged prion protein. PLoS One 4:e4446. CrossRef Medline

Sharples RA, Vella LJ, Nisbet RM, Naylor R, Perez K, Barnham KJ, Masters CL, Hill AF (2008) Inhibition of gamma-secretase causes increased secretion of amyloid precursor protein C-terminal fragments in association with exosomes. FASEB J 22:1469-1478. CrossRef Medline

Stöhr J, Watts JC, Legname G, Oehler A, Lemus A, Nguyen HO, Sussman J, Wille H, DeArmond SJ, Prusiner SB, Giles K (2011) Spontaneous generation of anchorless prions in transgenic mice. Proc Natl Acad Sci U S A 108:21223-21228. CrossRef Medline

Sturchler-Pierrat C, Abramowski D, Duke M, Wiederhold KH, Mistl C, Rothacher S, Ledermann B, Bürki K, Frey P, Paganetti PA, Waridel C, Calhoun ME, Jucker M, Probst A, Staufenbiel M, Sommer B (1997) Two amyloid precursor protein transgenic mouse models with Alzheimer disease-like pathology. Proc Natl Acad Sci U S A 94:13287-13292. CrossRef Medline

Vandermeeren M, Geraerts M, Pype S, Dillen L, Van Hove C, Mercken M (2001) The functional gamma-secretase inhibitor prevents production of amyloid beta 1-34 in human and murine cell lines. Neurosci Lett 315:145-148. CrossRef Medline

Vey M, Pilkuhn S, Wille H, Nixon R, DeArmond SJ, Smart EJ, Anderson RG, Taraboulos A, Prusiner SB (1996) Subcellular colocalization of the cellular and scrapie prion proteins in caveolae-like membranous domains. Proc Natl Acad Sci U S A 93:14945-14949. CrossRef Medline

Wang F, Yang F, Hu Y, Wang X, Jin C, Ma J (2007) Lipid interaction converts prion protein to a PrPSc-like proteinase K-resistant conformation under physiological conditions. Biochemistry 46:7045-7053. CrossRef Medline

Williamson R, Sutherland C (2011) Neuronal membranes are key to the pathogenesis of Alzheimer's disease: the role of both raft and non-raft membrane domains. Curr Alzheimer Res 8:213-221. CrossRef Medline

Yamaguchi H, Maat-Schieman ML, van Duinen SG, Prins FA, Neeskens P, Natté R, Roos RA (2000) Amyloid beta protein (Abeta) starts to deposit as plasma membrane-bound form in diffuse plaques of brains from hereditary cerebral hemorrhage with amyloidosis-Dutch type, Alzheimer disease and nondemented aged subjects. J Neuropathol Exp Neurol 59: 723-732. Medline

Yip CM, Elton EA, Darabie AA, Morrison MR, McLaurin J (2001) Cholesterol, a modulator of membrane-associated Abeta-fibrillogenesis and neurotoxicity. J Mol Biol 311:723-734. CrossRef Medline

Zhu M, Li J, Fink AL (2003) The association of alpha-synuclein with membranes affects bilayer structure, stability, and fibril formation. J Biol Chem 278:40186-40197. CrossRef Medline 